This item was submitted to Loughborough's Research Repository by the author.

Items in Figshare are protected by copyright, with all rights reserved, unless otherwise indicated.

\title{
Hydro-biogeochemical coupling beneath a large polythermal Arctic glacier: implications for subice sheet biogeochemistry
}

PLEASE CITE THE PUBLISHED VERSION

http://dx.doi.org/10.1029/2009JF001602

PUBLISHER

Wiley @ American Geophysical Union

VERSION

VoR (Version of Record)

LICENCE

CC BY-NC-ND 4.0

\section{REPOSITORY RECORD}

Wadham, Jemma, Martyn Tranter, A.J. Hodson, Richard Hodgkins, S. Bottrell, Richard Cooper, and R. Raiswell. 2019. "Hydro-biogeochemical Coupling Beneath a Large Polythermal Arctic Glacier: Implications for Subice Sheet Biogeochemistry". figshare. https://hdl.handle.net/2134/12977. 
This item was submitted to Loughborough's Institutional Repository (https://dspace.lboro.ac.uk/) by the author and is made available under the following Creative Commons Licence conditions.

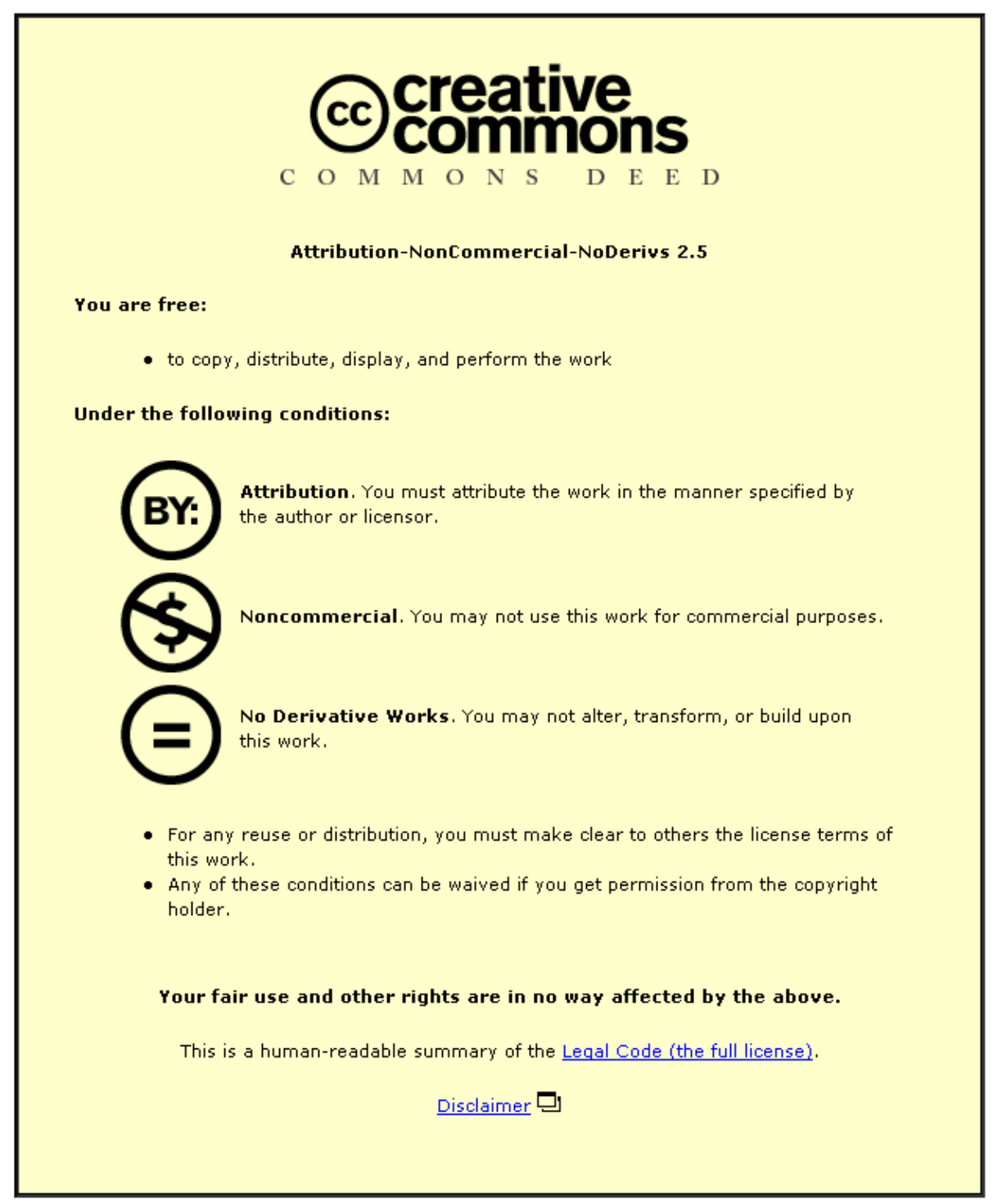

For the full text of this licence, please go to: http://creativecommons.org/licenses/by-nc-nd/2.5/ 


\title{
Hydro-biogeochemical coupling beneath a large polythermal Arctic glacier: Implications for subice sheet biogeochemistry
}

\author{
J. L. Wadham, ${ }^{1}$ M. Tranter, ${ }^{1}$ A. J. Hodson, ${ }^{2}$ R. Hodgkins, ${ }^{3}$ S. Bottrell, ${ }^{4}$ R. Cooper, ${ }^{5}$ \\ and R. Raiswell ${ }^{4}$ \\ Received 17 November 2009; revised 12 July 2010; accepted 16 July 2010; published 6 November 2010.
}

[1] We analyze the interannual chemical and isotopic composition of runoff from a large, high Arctic valley glacier over a 5 year period, during which drainage evolved from a long-residence-time drainage system feeding an artesian subglacial upwelling (SGU) at the glacier terminus to a shorter-residence-time drainage system feeding an ice-marginal channel (IMC). Increased icemelt inputs to the SGU are thought to have triggered this evolution. This sequence of events provides a unique opportunity to identify coupling between subglacial hydrology and biogeochemical processes within drainage systems of differing residence time. The biogeochemistry of the SGU is consistent with prolonged contact between meltwaters and subglacial sediments, in which silicate dissolution is enhanced, anoxic processes (e.g., sulphate reduction) prevail, and microbially generated $\mathrm{CO}_{2}$ and sulphide oxidation drive mineral dissolution. Solute in the IMC was mainly derived from moraine pore waters which are added to the channel via extraglacial streams. These pore waters acquire solute predominantly via sulphide oxidation coupled to carbonate/silicate dissolution. We present the first evidence that microbially mediated processes may contribute a substantial proportion ( $80 \%$ in this case) of the total glacial solute flux, which includes coupling between microbial $\mathrm{CO}_{2}$-generation and silicate/ carbonate dissolution. The latter suggests the presence of biofilms in subglacial/icemarginal sediments, where local perturbation of the geochemical environment by release of protons, organic acids, and ligands stimulates mineral dissolution. These data enable inferences to be made regarding biogeochemical processes in longer-residence-time glacial systems, with implications for the future exploration of Antarctic subglacial lakes and other wet-based ice sheet environments.

Citation: Wadham, J. L., M. Tranter, A. J. Hodson, R. Hodgkins, S. Bottrell, R. Cooper, and R. Raiswell (2010), Hydro-biogeochemical coupling beneath a large polythermal Arctic glacier: Implications for subice sheet biogeochemistry, J. Geophys. Res., 115, F04017, doi:10.1029/2009JF001602.

\section{Introduction}

[2] There is mounting evidence that the beds of glaciers and ice sheets are host to diverse communities of microorganisms [Sharp et al., 1999; Skidmore et al., 2000; Gaidos et al., 2004; Mikucki et al., 2004; Skidmore et al., 2005; Foght et al., 2004]. These microorganisms are intimately involved in chemical weathering, mediating both oxic and anoxic oxidation of sulphide minerals, the latter using $\mathrm{NO}_{3}^{-}$and $\mathrm{Fe}$ (III) [Bottrell and Tranter, 2002; Wadham et al., 2004; Wynn

\footnotetext{
${ }^{1}$ School of Geographical Sciences, University of Bristol, Bristol, UK. ${ }^{2}$ Department of Geography, University of Sheffield, Sheffield, UK. UK.

${ }^{3}$ Department of Geography, Loughborough University, Loughborough,

${ }^{4}$ School of Earth and Environment, Faculty of Environment, University of Leeds, Leeds, UK.

${ }^{5}$ The Macaulay Land Use Research Institute, Aberdeen, UK.
}

Copyright 2010 by the American Geophysical Union. 0148-0227/10/2009JF001602 et al., 2006], and adding $\mathrm{CO}_{2}$ to meltwaters through respiration [Tranter et al., 2002]. In doing so, they perturb local $\mathrm{pH} /$ Eh conditions and create microniches for microbial colonization [Tranter et al., 2005]. Recent work has highlighted the potential importance of these deep subsurface microbial communities in regulating global biogeochemical cycles. For example, the release of bioavailable iron from sediments in melting icebergs is a potential stimulant of ocean primary productivity, with consequent negative feedback effects on climatic warming via $\mathrm{CO}_{2}$ drawdown [Raiswell et al., 2006, 2008]. Others have suggested that anoxia generated beneath continental ice sheets may stimulate microorganisms to produce methane during periods of ice advance and carbon burial [Skidmore et al., 2000; Weitemeyer and Buffett, 2006; Wadham et al., 2008]. This methane may be stored as clathrate beneath the ice sheet until ice sheet decay stimulates its rapid release to the atmosphere [Weitemeyer and Buffett, 2006].

[3] While the activity of subglacial microbial communities in wet-based zones of glaciers and is well established 
Table 1. Description of Changes in Drainage on the Western Finsterwalderbreen Margin ${ }^{\mathrm{a}}$

\begin{tabular}{|c|c|c|c|c|}
\hline Year & Drainage Description & $\begin{array}{c}\text { Estimation of the \% of Meltwater } \\
\text { Routed by the SGU/IMC }\end{array}$ & Data Employed in This Study & Source Data \\
\hline 1994 & SGU sustained for the 1994 melt season & $<10 \% />90 \%$ & SGU major ion chemistry & Wadham et al. [1998] \\
\hline 1995 & $\begin{array}{l}\text { SGU sustained for the } 1995 \text { season and } \\
\text { routed snowmelt to the terminus } \\
\text { via debris layer }\end{array}$ & $<10 \% />90 \%$ & SGU major ion chemistry & Wadham et al. [1998] \\
\hline 1997 & $\begin{array}{l}\text { SGU captures drainage from IMC and } \\
\text { conveys } 90 \% \text { of meltwater drainage } \\
\text { on the western margin }\end{array}$ & $>90 \% /<10 \%$ & $\begin{array}{l}\text { SGU major ion chemistry plus } \delta^{18} \mathrm{O} \\
\text { and } \delta^{34} \mathrm{~S} \text { of sulphate }\end{array}$ & Wadham et al. [2004] \\
\hline 1999 & $\begin{array}{l}\text { SGU no longer present, and } \\
\text { all meltwater emerged via the IMC }\end{array}$ & $0 \% / 100 \%$ & $\begin{array}{l}\text { SGU major ion chemistry, plus } \delta^{18} \mathrm{O} \\
\text { and } \delta^{34} \mathrm{~S} \text { of sulphate }\end{array}$ & $\begin{array}{l}\text { Wadham et al. [2007]; } \\
\text { Cooper et al. [2002] }\end{array}$ \\
\hline
\end{tabular}

${ }^{\mathrm{a}}$ Data presented in this paper and source references.

[Tranter et al., 2005], there is little data on microbial processes beneath ice sheets and the sensitivity of subglacial biogeochemistry to temporal shifts in the configuration and characteristics of meltwater flow paths. Any reorganization of subglacial flow paths and associated changes in meltwater residence times and rock:water ratios will impact on the balance of biogeochemical processes and associated export of key nutrients to downstream environments. Valley glaciers possess dynamic subglacial drainage systems, which evolve seasonally from long-residence-time distributed drainage systems (residence times of days to months) to discrete networks of channels (residence times of hours) [Nienow et $a l ., 1998]$. Recent work has demonstrated the presence of subglacial meltwater routing at the base of the Greenland Ice Sheet, driven by rapid drainage of surface lakes [Das et al., 2008]. Beneath Antarctica subglacial lakes form via the accumulation of meltwater generated by geothermal heating of basal ice, and periodically drain when their volume attains a critical threshold [Wingham et al., 2006; Fricker et al., 2007]. This suggests that some of the basal regions of ice sheets may evolve their drainage system structure over time, with consequent perturbation of subglacial biogeochemistry and microbial community composition [Tranter et al., 2005; Hodson et al., 2008]. While hydro-biogeochemical data from ice sheets is sparse, insights into the coupling between hydrological drainage system evolution and subglacial biogeochemistry can be gained from large valley glacier systems. Here, a polythermal regime (similar to that on ice sheet margins) and longer flow paths for meltwaters (and hence, longer water residence times) provide case studies that are intermediate between small, temperate valley glaciers and continentalscale ice sheets.

[4] We employ the interannual chemical and isotopic composition of runoff from a large, high Arctic valley glacier, Finsterwalderbreen (Svalbard), over a 5 year period (1994-1999) to infer changes in subglacial biogeochemistry associated with drainage reorganization. Previous work from individual years [Wadham et al., 1998, 2000, 2004, 2007] has indicated that two principal drainage systems contribute runoff to the western glacier margin: a predominantly longresidence-time drainage system feeding an artesian subglacial upwelling outflow (SGU) and a shorter residence time channelized drainage system, which culminates in an icemarginal channel (IMC). We estimate that residence times in the SGU are $>1$ day, and a matter of hours in the IMC.
Independent hydrological observations over the 5 year study period clearly indicate that the SGU routed an increasing proportion of runoff on the western margin between 1994 and 1997, accounting for $90 \%$ of runoff by 1997 and forming an artesian fountain $>1 \mathrm{~m}$ high at the terminus. However, the SGU was no longer present during the summers of 1999 and 2000 and all runoff was routed entirely by the IMC, signifying a shift in meltwater routing. This sequence of events provides a unique opportunity to identify (1) the forcing mechanisms for this subglacial drainage evolution and (2) modes of coupling between subglacial biogeochemistry and hydrology on larger glacier systems during drainage reorganization. In doing so, it provides a framework for testing a series of hypotheses regarding biogeochemical processes beneath continental-scale ice sheets (e.g., Antarctic subglacial lakes and their interconnecting flow paths). It has particular relevance to the Greenland Ice Sheet under climate warming scenarios where an increased extent of surface melting may initiate surface to bed hydrological coupling for the first time in areas where previously all melt was supplied from basal melting and routed via a distributed drainage system [Steffen et al., 2004].

\section{Field Study Area}

[5] Finsterwalderbreen $\left(77^{\circ} 28^{\prime} \mathrm{N}, 15^{\circ} 18^{\prime} \mathrm{E}\right)$ is located on the southern side of Van Keulenfjorden, Spitsbergen. The active glacier is $35 \mathrm{~km}^{2}$ in area, $11 \mathrm{~km}$ in length and is polythermal [Wadham et al., 1998]. The lithology is mainly sedimentary, with the upper catchment and headwalls consisting of Precambrian carbonates, phyllite and quartzite, Permian sandstones, dolomite and limestones and the rest of the catchment comprising Triassic to Cretaceous siltstones, sandstones and shales [Dallmann et al., 1990].

[6] Details of meltwater drainage are discussed previously by Wadham et al. [1998, 2000, 2004, 2007], and indicate that $\sim 70 \%$ of the glacier's meltwaters drain from the western margin via the SGU and IMC. The relative dominance of these two pathways altered markedly between 1994 and 1999, and a summary of this behavior is included in Table 1 . We subdivide the 5 years of study into two periods based upon the principle route taken by subglacial meltwaters: the Artesian Drainage Period (AD period) (1994-1997), when the SGU contributed subglacial meltwaters to runoff on the western margin and the Channelized Drainage Period (CD period) (1999), when the SGU was no longer active and all 


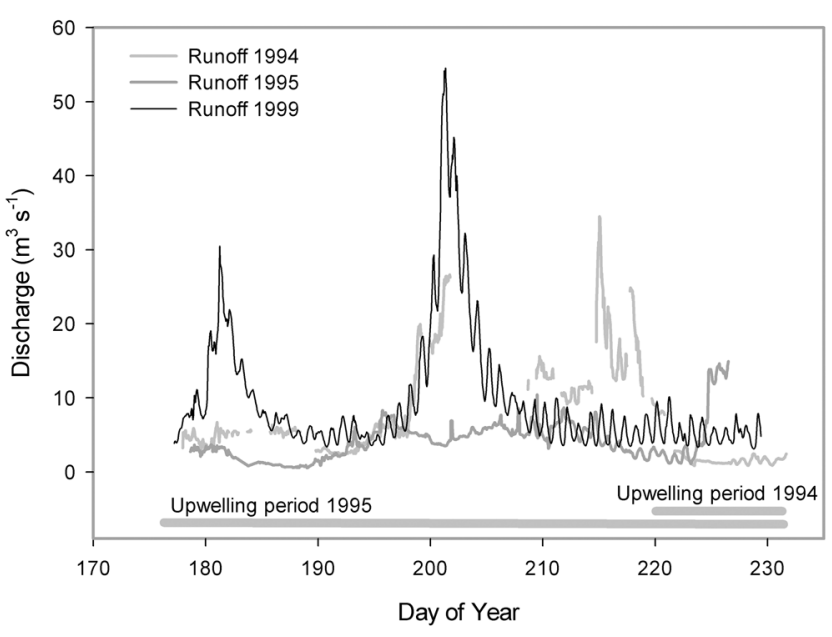

Figure 1. Time series of bulk meltwater discharge for the 1994, 1995 (AD period), and 1999 (CD period) melt seasons. Time periods when then SGU was active are shown for 1994 and 1995.

runoff was routed to the margin by channels, culminating in the IMC.

\section{Methods}

[7] Full details of sampling procedures for individual years have been described previously (see Table 1 for source). In brief, manual samples were collected daily from the SGU in 1994 (Days 222-231) and 1995 (Days 177-221) and twice daily in 1997 (Days 183-195). No runoff sampling was conducted in 1996 or 1998 . The 1997 SGU samples can also be considered as bulk runoff samples, since the SGU dominated western margin drainage in this year. Daily bulk runoff samples were taken in 1999, which issued from the IMC following SGU evolution. Samples were analyzed for the major cations and anions by ion chromagraphy on a Dionex $4000 \mathrm{i}$ Ion Chromatograph, where precision and accuracy of analyses was \pm 2 and $\pm 10 \%$, respectively. Alkalinity was calculated from charge balance. Dissolved Si was determined colorimetrically following methods by Wadham et al. [2000] and precision and accuracy were $\pm 3.4 \%$ and $\pm 6.7 \%$, respectively. Isotopic determinations on 1997 samples are described by Wadham et al. [2004]. The isotopic composition of sulphate in 1999 runoff was determined following these methods and those reported by Wadham et al. [2007]. In short, the $\delta^{18} \mathrm{O}-\mathrm{SO}_{4}^{2-}$ of the samples was determined by $\mathrm{CO}_{2}$ equilibration (standard $=\mathrm{SMOW}$ ). The sulphate in these samples was recovered as $\mathrm{BaSO}_{4}$ for the analysis of $\delta^{34} \mathrm{~S}$ and $\delta^{18} \mathrm{O}-\mathrm{SO}_{4}^{2-}$ (standard $=\mathrm{CDT}$ and SMOW, respectively). Isotopic analyses were made on a VG SIRA10 isotope ratio mass spectrometer at the University of Leeds. Methods for bulk discharge monitoring in 1994, 1995 and 1999 can be found in the works by Wadham et al. [1998] and Cooper et al. [2002].

\section{Results}

\subsection{Major Ion Chemistry}

[8] Major ion chemical data are available in all years, with $\delta^{34} \mathrm{~S}$ and $\delta^{18} \mathrm{O}$ isotopes on sulphate for 1997 and 1999
(Table 1). Cation and sulphate concentrations are corrected for the snowpack contribution using ion ratios to chloride as reported previously [Wadham et al., 1998, 2004, 2007]. Hence, all concentrations reported are derived from rock weathering alone.

[9] We employ the concentrations of a variety of chemical indices in order to infer forcing mechanisms for hydrological evolution and associated shifts in biogeochemical processes during the $\mathrm{AD}$ period and between the $\mathrm{AD}$ and CD periods. Specifically, we conduct three comparisons, described below, to facilitate this analysis: (1) hydrological forcing, (2) SGU biogeochemical evolution, and (3) AD to CD biogeochemical evolution.

[10] 1. We employ discharge data and $\mathrm{Cl}^{-}$concentrations in meltwaters to indicate hydrological forcing for the drainage reorganization observed during the 5 year study period. $\mathrm{Cl}^{-}$ is derived from snowmelt, and is generally absent from icemelt [Wadham et al., 1998]. Hence, interseasonal differences in $\mathrm{Cl}^{-}$are used to indicate contrasts in these two meltwater sources during and between the $\mathrm{AD}$ and $\mathrm{CD}$ periods. We also compare total bulk discharge variations and the relationship between $\mathrm{Cl}^{-}$and discharge for 1994 and 1995 (AD period) and 1999 (CD period) in order to infer the degree to which any interannual differences in meltwater sourcing might be a function of varying surface melt rates (and hence discharge).

[11] 2. The chemical composition of meltwaters issuing from the SGU between 1994 and 1997 is compared in order to identify any trends in subglacial biogeochemistry during the AD period. Specifically, we compare associations between the major crustal-derived ions and ion ratios.

[12] 3. We compare the chemistry of the western margin bulk runoff between 1997 (using data from the SGU, which dominated bulk discharge) and 1999 (when the SGU was absent and the IMC dominated discharge) in order to determine biogeochemical evolution between the CD and the AD periods. We do not present the full crustal chemical data for bulk runoff in 1994 and 1995, since chemical trends in these years mainly reflect mixing processes and the relative contributions of the SGU and IMC to total bulk discharge [Wadham et al., 1998]. Associations between bulk meltwater * $\mathrm{SO}_{4}^{2-}$ concentrations and discharge in 1994-1995 and 1999 are employed purely to indicate changes in these mixing processes.

\subsection{Hydrological Forcing}

[13] Seasonal time series of bulk meltwater discharge from the western margin in 1994, 1995 (AD period) and 1999 (CD period) are displayed in Figure 1. The bulk discharge regime in 1999 differs fundamentally from that in 1994 and 1995 in two significant ways. First, there is a period of unusually high spring discharge in 1999 of up to $30 \mathrm{~m}^{3} \mathrm{~s}^{-1}$, compared with 1994 and 1995 when early season discharges were generally $<5 \mathrm{~m}^{3} \mathrm{~s}^{-1}$. Second, the occurrence of a midseason outburst event in 1999 [Wadham et al., 2001] produces peak discharges double those in 1994 and 1995. These outburst events are commonly observed on the western margin of the glacier in summer and have been discussed previously [Wadham et al., 2001].

[14] Figure 2a displays the temporal variation in $\mathrm{Cl}^{-}$ concentrations in SGU meltwaters during the $\mathrm{AD}$ period, and Figure $2 \mathrm{~b}$ compares $\mathrm{Cl}^{-}$concentrations between bulk 

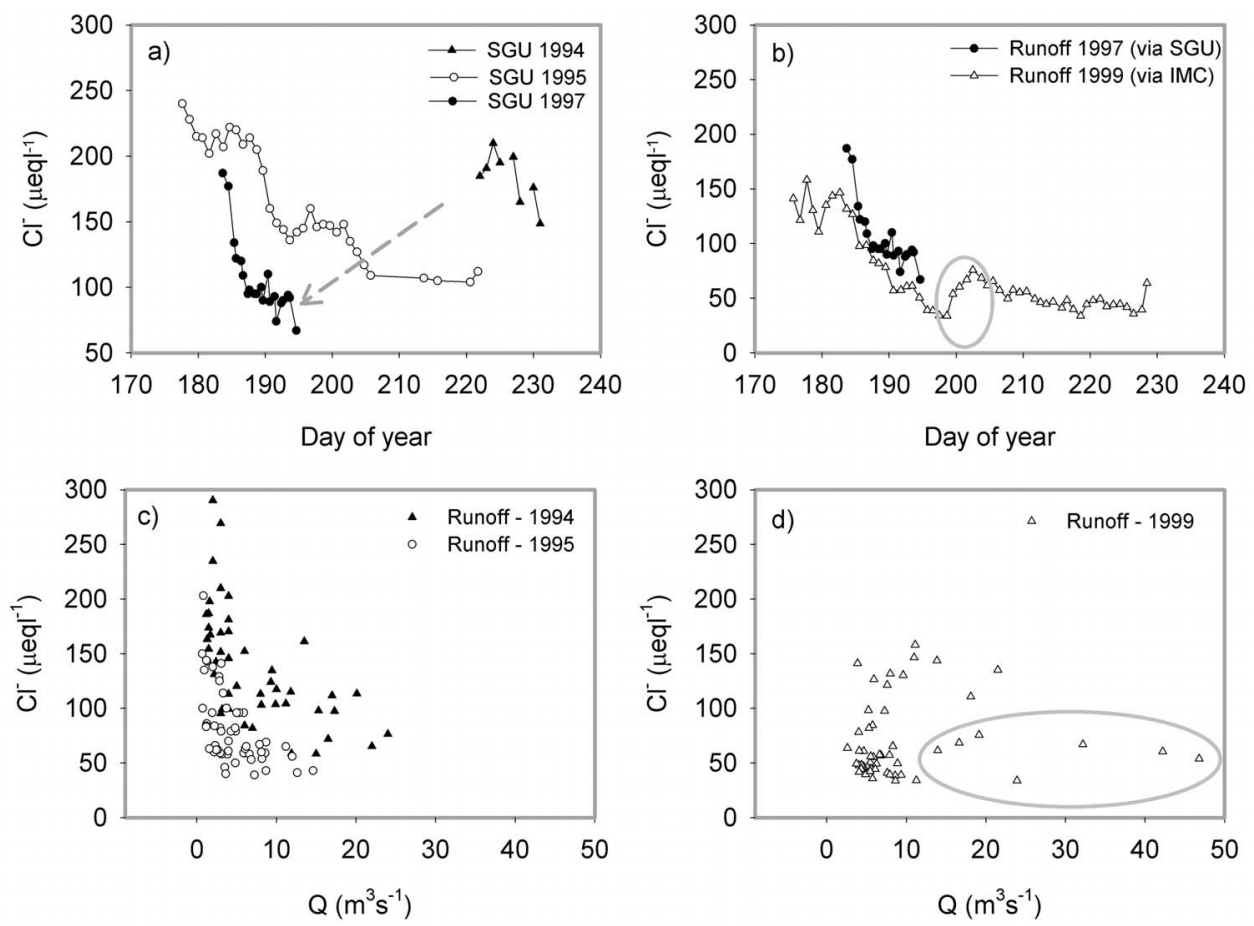

Figure 2. Temporal evolution in $\mathrm{Cl}^{-}$concentrations in (a) SGU meltwaters between 1994 and 1997 (where the arrow indicates the direction of change over the 4 year period when the SGU was active) and (b) in bulk runoff between 1997 and 1999. The short time series for 1994 SGU data in Figures 2a and $2 \mathrm{~b}$ reflects the fact that this outflow was only active for a short period in this year. Associations between bulk meltwater $\mathrm{Cl}^{-}$concentrations and bulk meltwater discharge (IMC+SGU runoff) are presented for (c) the AD period (1994 and 1995) and (d) the CD period (1999). Data points affected by an outburst event in 1999 are circled in Figures $2 \mathrm{~b}$ and 2d.

runoff sampled during the $\mathrm{AD}$ period (1997) and $\mathrm{CD}$ period (1999), when the SGU and IMC, respectively, dominated discharge at the western margin. There is a very clear trend of decreasing $\mathrm{Cl}^{-}$in all waters sampled from the beginning to the end of each monitoring period. This is matched by decreasing concentrations of $\mathrm{Cl}^{-}$in SGU meltwaters from 1994 to 1997 and in bulk runoff from 1997 to 1999. The association between bulk meltwater $\mathrm{Cl}^{-}$concentrations and bulk meltwater discharge for the AD period (1994, 1995) and CD period (1999) is displayed in Figures 2c and 2d. While seasonal decreases in $\mathrm{Cl}^{-}$generally correlate with increasing discharge, interseasonal concentrations of $\mathrm{Cl}^{-}$ between the $\mathrm{AD}$ and $\mathrm{CD}$ periods cannot be explained by discharge alone. For example, bulk meltwater $\mathrm{Cl}^{-}$concentrations in the CD period (1999) are lower than those from the AD period (1994-1997) for the same discharge. During the AD period, there is also a decrease in bulk meltwater $\mathrm{Cl}^{-}$concentrations for the equivalent discharge from 1994 to 1995 . There is no significant relationship between $\mathrm{Cl}^{-}$and discharge in 1999. As reported elsewhere, some of the higher discharge points $\left(>15 \mathrm{~m}^{3} \mathrm{~s}^{-1}\right)$ in this year refer to a subglacial outburst event [Wadham et al., 2001].

\subsection{Biogeochemical Evolution}

[15] The concentration of sulphate, derived from the oxidation of sulphide minerals [Wadham et al., 2004], displays similar trends to $\mathrm{Cl}^{-}$both within and between individual years
(Figures $3 \mathrm{a}$ and $3 \mathrm{~b}$ ). A notable exception is the low $* \mathrm{SO}_{4}^{2-}$ observed in the $1997 \mathrm{AD}$ period meltwaters relative to all other samples. In general, the bulk meltwater $\mathrm{SO}_{4}^{2-}$ concentrations were higher and much more strongly correlated with bulk meltwater discharge during the AD period (1994 and 1995: $\mathrm{R}^{2}=0.72$ and 0.59 , respectively) relative to the $\mathrm{CD}$ period $\left(1999: \mathrm{R}^{2}=0.41\right)$. As for $\mathrm{Cl}^{-}$, relatively constant $* \mathrm{SO}_{4}^{2-}$ concentrations in 1999 data for some of the discharge points $>15 \mathrm{~m}^{3} \mathrm{~s}^{-1}$ reflects a subglacial outburst event [Cooper et al., 2002].

[16] Associations between different ions can be used to infer the dominant chemical weathering processes in meltwaters during and between the $\mathrm{AD}$ and $\mathrm{CD}$ periods. Associations between the major ions and dissolved $\mathrm{Si}$ are presented in Figure 4, with the gradients, intercepts and $R^{2}$ values for these associations described in Table 2. We remove the ion data associated with the subglacial outburst event in 1999, which briefly perturbed bulk meltwater solute chemistry. Plots presented in Figure 4 highlight distinct evolutionary trends both during the $\mathrm{AD}$ period and between the $\mathrm{AD}$ and $\mathrm{CD}$ periods. Relationships between ${ }^{*} \mathrm{SO}_{4}^{2-}$ and $\mathrm{HCO}_{3}^{-}$are generally strong during the AD period (apart from 1994, where the small number of data points and the low gradient makes this relationship statistically insignificant) (Figure 4a). There is no relationship between $\mathrm{HCO}_{3}^{-}$and $* \mathrm{SO}_{4}^{2-}$ during the $\mathrm{CD}$ period. This suggests that there was a change in the biogeochemical dissolution processes supplying sulphate 

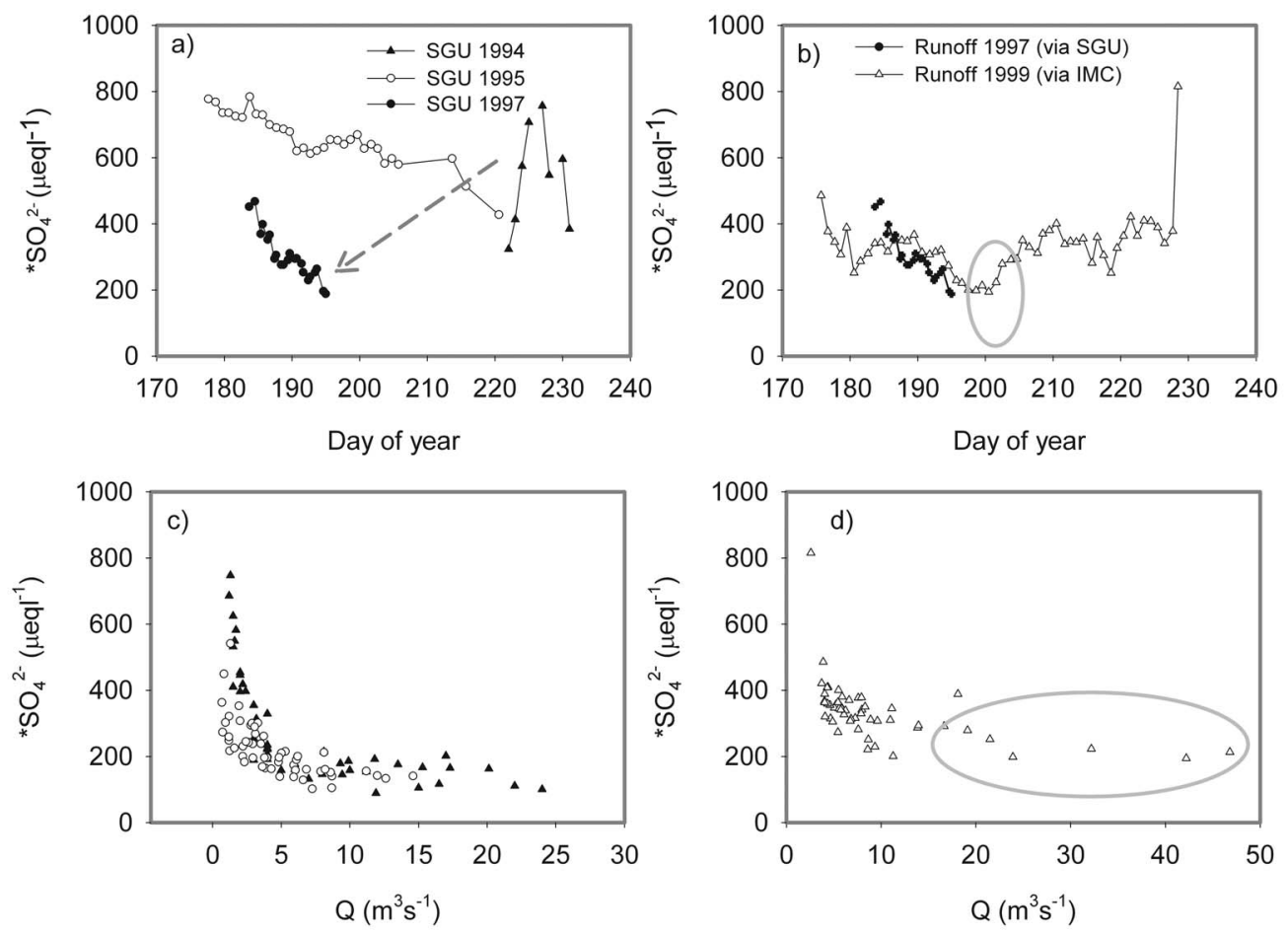

Figure 3. Temporal evolution in $\mathrm{SO}_{4}^{2-}$ concentrations in (a) SGU meltwaters between 1994 and 1997 (where the arrow indicates the direction of change over the 4 year period when the SGU was active) and (b) in bulk runoff between 1997 and 1999. The short time series for 1994 SGU data in Figures 3a and $3 \mathrm{~b}$ reflects the fact that this outflow was only active for a short period in this year. Associations between bulk meltwater $\mathrm{SO}_{4}^{2-}$ concentrations and bulk meltwater discharge (IMC+SGU runoff) are presented for (c) the AD period (1994 and 1995) and (d) the CD period (1999). Data points affected by an outburst event in 1999 are circled in Figures 3b and 3d.

from the $\mathrm{AD}$ period to the $\mathrm{CD}$ period. Intercepts in plots of $\mathrm{HCO}_{3}^{-}$against $* \mathrm{SO}_{4}^{2-}$ and ${ }^{*} \mathrm{Ca}^{2+}+* \mathrm{Mg}^{2+}$ against $* \mathrm{SO}_{4}^{2-}$ in all meltwaters sampled are high (Figures $4 \mathrm{a}$ and $4 \mathrm{~b}$ ) and exceed the theoretical value for carbonate hydrolysis $\left(=220 \mu \mathrm{eq} \mathrm{L}{ }^{-1}\right)$ [Tranter et al., 2002].

[17] Slopes of associations between $\mathrm{HCO}_{3}^{-}$and ${ }^{*} \mathrm{SO}_{4}^{2-}$ (Figure 4a) and ${ }^{*} \mathrm{Ca}^{2+}+* \mathrm{Mg}^{2+}$ and ${ }^{*} \mathrm{SO}_{4}^{2}$ (Figure $4 \mathrm{~b}$ ) are low during the AD period $\left(0.28\right.$ and 0.66 for $\mathrm{HCO}_{3}^{-} / \mathrm{SO}_{4}^{2-}$ in 1994 and 1997, respectively, and 1.28 and 1.34 for $\mathrm{Ca}^{2+}+\mathrm{Mg}^{2+} / \mathrm{SO}_{4}^{2-}$ in 1994 and 1997 , respectively), while concentrations of $* \mathrm{Na}^{+}$and ${ }^{*} \mathrm{~K}^{+}$are high (Figures $4 \mathrm{~d}$ and $4 \mathrm{e})$. Both these features are consistent with the dissolution of silicate minerals by protons generated during sulphide oxidation [Tranter et al., 2002]. The 1995 SGU waters represent an enigma here since they display the highest concentrations of $* \mathrm{Na}^{+}$and $* \mathrm{~K}^{+}$of all waters sampled (Figure 4e), but have high slope values in both relationships of $\mathrm{HCO}_{3}^{-}$against $* \mathrm{SO}_{4}^{2-}$ (gradient $\left.=1.4\right)$ and $* \mathrm{Ca}^{2+}+* \mathrm{Mg}^{2+}$ against ${ }^{*} \mathrm{SO}_{4}^{2-}($ gradient $=1.82)($ Table 2$)$. The regression line for the association between $\mathrm{SO}_{4}^{2-}$ and ${ }^{*} \mathrm{Ca}^{2+}+* \mathrm{Mg}^{2+}$ for the 1999 bulk meltwaters was lower (slope $=1$ in 1999) (Table 2) than those for the SGU meltwaters in all years, as determined by ANCOVA one way tests (at the $99 \%$ confidence level). Decreases in the concentrations of $* \mathrm{Na}^{+}$and ${ }^{*} \mathrm{~K}^{+}$from 1994/ 1995 to 1997 during the AD period (Figure 4e) suggest a diminishing importance of silicate dissolution as the SGU evolves hydrologically. ${ }^{*} \mathrm{Na}^{+}$and ${ }^{*} \mathrm{~K}^{+}$display slightly higher concentrations in bulk runoff from the SGU compared to the CD period (Figure 4e). The relationship between ${ }^{*} \mathrm{Na}^{+}+{ }^{*} \mathrm{~K}^{+}$ concentrations and $\mathrm{HCO}_{3}^{-}$(Figure 4e) is markedly stronger than that with $\mathrm{SO}_{4}^{2-}$ for most waters sampled (Figure 4d), suggesting that ${ }^{*} \mathrm{Na}^{+}$and $* \mathrm{~K}^{+}$are principally acquired with $\mathrm{HCO}_{3}^{-}$, rather than $\mathrm{SO}_{4}^{2-}$.

[18] Associations between ratios of $\left({ }^{*} \mathrm{Ca}^{2+}+* \mathrm{Mg}^{2+}\right)$ : $\left(* \mathrm{Na}^{+}+* \mathrm{~K}^{+}\right),{ }^{*} \mathrm{~K}^{+}: * \mathrm{Na}^{+}$and $* \mathrm{Ca}^{2+}: * \mathrm{Mg}^{2+}$ (Figure 5) and ionic strength can be used to infer the changing dominance of chemical dissolution processes with changing residence time during and between the $\mathrm{AD}$ and $\mathrm{CD}$ periods. Whereas divalent ions are usually derived from carbonate weathering (carbonate and dolomite), $\mathrm{Na}^{+}$and $\mathrm{K}^{+}$are derived predominantly from the dissolution of silicate minerals. Hence, ratios of $\left({ }^{*} \mathrm{Ca}^{2+}+* \mathrm{Mg}^{2+}\right):\left({ }^{*} \mathrm{Na}^{+}+* \mathrm{~K}^{+}\right)$can be used to indicate the relative dominance of carbonate versus silicate dissolution. $\mathrm{K}^{+}$derives predominantly from the dissolution of biotite, released nonstoichiometrically from the bedrock during subglacial comminution [Anderson, 2007]. Thus, ratios of $* \mathrm{~K}^{+}: * \mathrm{Na}^{+}$can be used to indicate the contribution to total runoff by meltwaters draining areas of the glacier bed where there is active comminution (e.g., distributed system). Ratios of ${ }^{*} \mathrm{Ca}^{2+}: * \mathrm{Mg}^{2+}$ indicate the relative importance of dolomite verses carbonate dissolution, since a proportion of $\mathrm{Mg}^{2+}$ released is greater by dolomite dissolution. Typically, the 

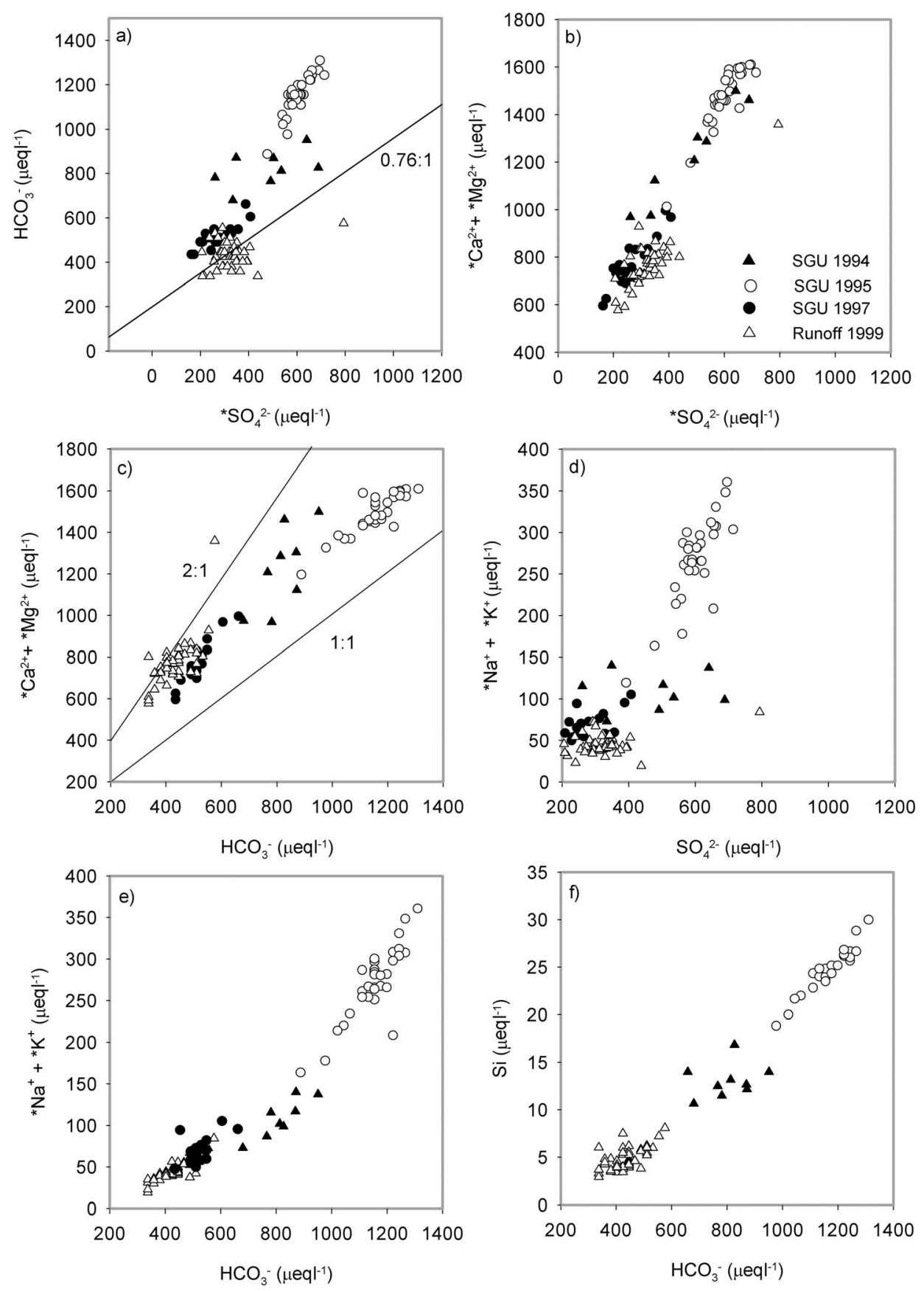

Figure 4. Associations between (a) $\mathrm{HCO}_{3}^{-}$and $* \mathrm{SO}_{4}^{2-}$, (b) $* \mathrm{Ca}^{2+}+* \mathrm{Mg}^{2+}$ and $* \mathrm{SO}_{4}^{2-}$, (c) $* \mathrm{Ca}^{2+}+* \mathrm{Mg}^{2+}$ and $\mathrm{HCO}_{3}^{-}$, (d) $* \mathrm{Na}^{+}+* \mathrm{~K}^{+}$and $* \mathrm{SO}_{4}^{2-}$, (e) $* \mathrm{Na}^{+}+* \mathrm{~K}^{+}$and $\mathrm{HCO}_{3}^{-}$, and (f) $\mathrm{Si}$ and $\mathrm{HCO}_{3}^{-}$in SGU (19941997) meltwaters and 1999 runoff.

proportion of dolomite dissolution increases with increased meltwater residence time [Sharp et al., 2002]. Figure 5a indicates that there is a progressive increase in the ratio of divalent to monovalent ions with decreasing ionic strength and moving from the $\mathrm{AD}$ to $\mathrm{CD}$ period. Comparison of bulk meltwaters from the SGU (1997) and IMC (1999) periods indicates higher ionic strength and lower ratios of $\left({ }^{*} \mathrm{Ca}^{2+}+* \mathrm{Mg}^{2+}\right):\left({ }^{*} \mathrm{Na}^{+}+* \mathrm{~K}^{+}\right)$in the former case. Ratios of ${ }^{*} \mathrm{~K}^{+}: * \mathrm{Na}^{+}$and ${ }^{*} \mathrm{Ca}^{2+}+: * \mathrm{Mg}^{2+}$ show similar trends with ionic strength for the different years and periods (Figures 5a and $5 b$ ).

[19] Data on the $\delta^{34} \mathrm{~S}$ and $\delta^{18} \mathrm{O}$ composition of sulphate exist for bulk runoff from the AD (1997) and CD (1999) periods, when the SGU and IMC, respectively, dominated runoff. The 1997 data are discussed by Wadham et al. [2004]. The $\delta^{34} \mathrm{~S}$ values during the AD period plot in a steep array, with the $\delta^{34} \mathrm{~S}$ inverse to the sulphate mass fraction of $\mathrm{SO}_{4}^{2-}:\left(\mathrm{SO}_{4}^{2-}+\mathrm{HCO}_{3}^{-}\right)$(hereafter "SMF") 
Table 2. Best Fit Simple Linear Regressions for Equations for Meltwaters Sampled From the Terminus Between 1994 and $1999^{\mathrm{a}}$

\begin{tabular}{|c|c|c|c|c|}
\hline & AD period 1994 & AD period 1995 & AD period 1997 & CD period 1999 \\
\hline $\begin{array}{l}\mathrm{HCO}_{3}^{-} \\
* \mathrm{Ca}^{2+}+* \mathrm{Mg}^{2+} \\
* \mathrm{Na}^{+}+* \mathrm{~K}^{+} \\
\mathrm{Si}\end{array}$ & $\begin{array}{c}{[\mathrm{y}=0.280 \mathrm{x}+688]} \\
\left(\mathrm{n}=8, \mathrm{R}^{2}=0.27\right) \\
\mathrm{y}=1.28 \mathrm{x}+619 \\
\left(\mathrm{n}=8, \mathrm{R}^{2}=0.94\right) \\
{[\mathrm{y}=0.010 \mathrm{x}+104]} \\
\left(\mathrm{n}=8, \mathrm{R}^{2}=0.005\right) \\
\mathrm{y}=0.012 \mathrm{x}+7.80 \\
\left(\mathrm{n}=9, \mathrm{R}^{2}=0.77\right)\end{array}$ & $\begin{array}{c}\text { Versus } S O_{4}^{2-} \\
\mathrm{y}=1.44 \mathrm{x}+278 \\
\left(\mathrm{n}=32, \mathrm{R}^{2}=0.77\right) \\
\mathrm{y}=1.82 \mathrm{x}+379 \\
\left(\mathrm{n}=33, \mathrm{R}^{2}=0.84\right) \\
\mathrm{y}=0.66 \mathrm{x}-129 \\
\left(\mathrm{n}=32, \mathrm{R}^{2}=0.67\right) \\
\mathrm{y}=0.04 \mathrm{x}-0.88 \\
\left(\mathrm{n}=54, \mathrm{R}^{2}=0.78\right)\end{array}$ & $\begin{array}{c}\mathrm{y}=0.660 \mathrm{x}+340 \\
\left(\mathrm{n}=21, \mathrm{R}^{2}=0.7\right) \\
\mathrm{y}=1.34 \mathrm{x}+415 \\
\left(\mathrm{n}=22, \mathrm{R}^{2}=0.81\right) \\
\mathrm{y}=0.160 \mathrm{x}+26.0 \\
\left(\mathrm{n}=19, \mathrm{R}^{2}=0.43\right)\end{array}$ & $\begin{array}{c}{[\mathrm{y}=0.210 \mathrm{x}+359]} \\
\left(\mathrm{n}=54, \mathrm{R}^{2}=0.11\right) \\
\mathrm{y}=1.11+408 \\
\left(\mathrm{n}=54, \mathrm{R}^{2}=0.74\right) \\
{[\mathrm{y}=0.05 \mathrm{x}+27.5]} \\
\left(\mathrm{n}=54, \mathrm{R}^{2}=0.15\right) \\
{[\mathrm{y}=0.005 \mathrm{x}+2.97} \\
\left(\mathrm{n}=54, \mathrm{R}^{2}=0.17\right)\end{array}$ \\
\hline $\begin{array}{l}* \mathrm{Ca}^{2+}+* \mathrm{Mg}^{2+} \\
* \mathrm{Na}^{+}+* \mathrm{~K}^{+} \\
\mathrm{Si}\end{array}$ & $\begin{array}{c}\mathrm{y}=1.75 \mathrm{x}-213 \\
\left(\mathrm{n}=8, \mathrm{R}^{2}=0.51\right) \\
\mathrm{y}=0.250 \mathrm{x}-97.5 \\
\left(\mathrm{n}=8, \mathrm{R}^{2}=0.77\right) \\
{[\mathrm{y}=0.011 \mathrm{x}+5.30]} \\
\left(\mathrm{n}=9, \mathrm{R}^{2}=0.17\right)\end{array}$ & $\begin{aligned} & \text { Versus } \mathrm{HCO}_{3}^{-} \\
& \mathrm{y}= 0.940 \mathrm{x}+396 \\
&(\mathrm{n}=\left.31, \mathrm{R}^{2}=0.77\right) \\
& \mathrm{y}= 0.427 \mathrm{x}-220 \\
&(\mathrm{n}=32, \mathrm{R}=0.74) \\
& \mathrm{y}=0.030 \mathrm{x}-8.30 \\
&\left(\mathrm{n}=30, \mathrm{R}^{2}=0.90\right)\end{aligned}$ & $\begin{array}{c}\mathrm{y}=1.79 \mathrm{x}-149 \\
\left(\mathrm{n}=22, \mathrm{R}^{2}=0.89\right) \\
\mathrm{y}=0.190 \mathrm{x}-32.0 \\
\left(\mathrm{n}=19, \mathrm{R}^{2}=0.39\right)\end{array}$ & $\begin{array}{c}\mathrm{y}=1.31 \mathrm{x}+201 \\
\left(\mathrm{n}=54, \mathrm{R}^{2}=0.45\right) \\
\mathrm{y}=0.190 \mathrm{x}-37.0 \\
\left(\mathrm{n}=54, \mathrm{R}^{2}=0.78\right) \\
\mathrm{y}=0.040 \mathrm{x}-1.50 \\
\left(\mathrm{n}=54, \mathrm{R}^{2}=0.4\right)\end{array}$ \\
\hline
\end{tabular}

${ }^{a}$ Regression equations in parentheses are not significant at the $95 \%$ confidence limit.

(Figure 6a). The lower end of this range corresponds to values typical of bedrock sulphide at $-17.94 \%$ [Wadham et al., 2007]. Although the $\delta^{34} \mathrm{~S}$ of $\mathrm{CD}$ runoff plots across the same range as that for the AD period, there is no significant association with SMF in the former case. There is also no temporal trend in $\delta^{34} \mathrm{~S}$ values from the IMC (time series not shown). The $\delta^{18} \mathrm{O}$ of sulphate in the SGU meltwaters displays consistent values of around $+25-27 \%$ (Figure 6b), which are about 35\% heavier than CD meltwaters. This signifies a major shift in the isotopic
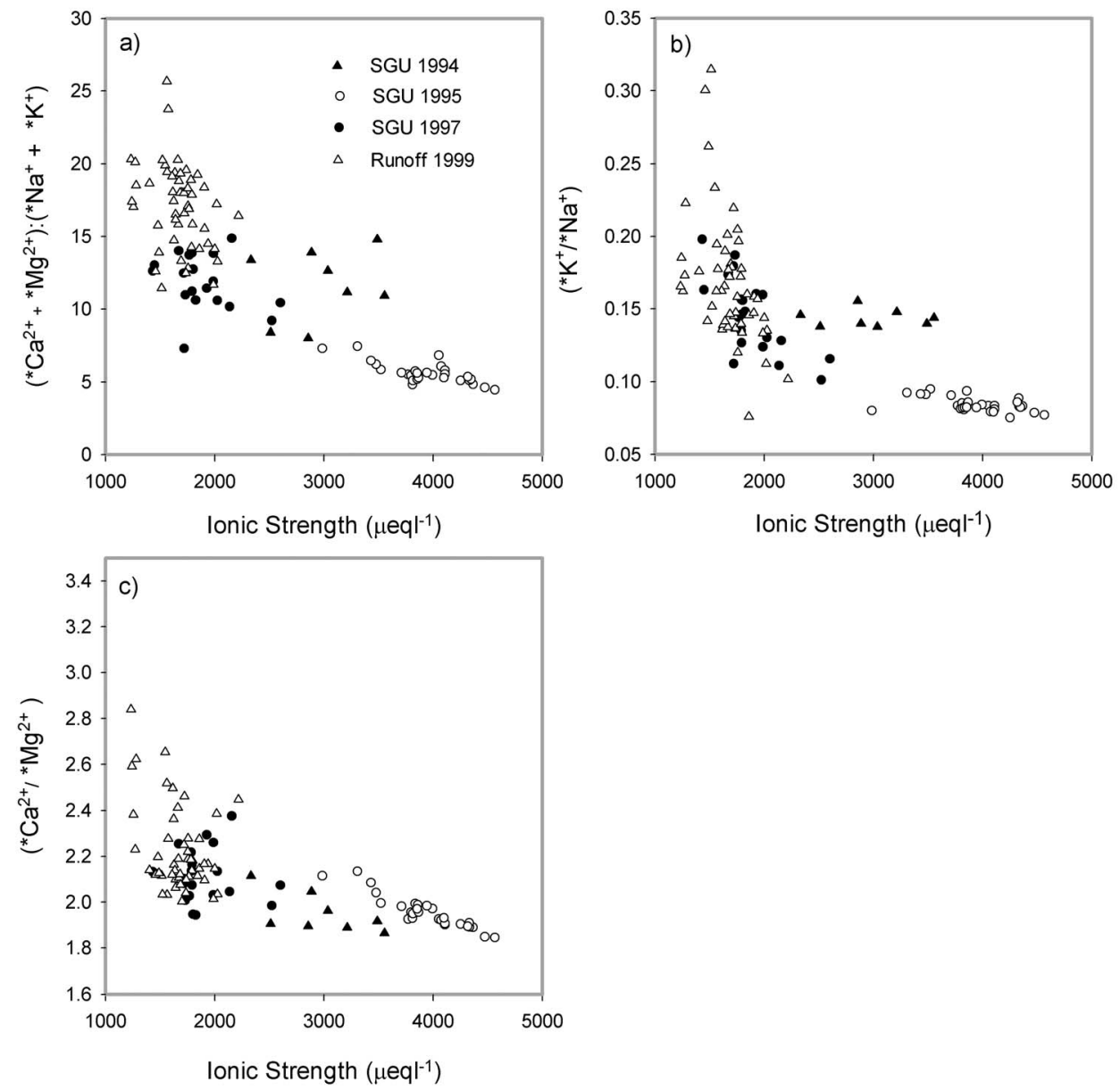

Figure 5. Associations between ionic strength and (a) $\left(* \mathrm{Ca}^{2+}+* \mathrm{Mg}^{2+}\right):\left(* \mathrm{Na}^{+}+* \mathrm{~K}^{+}\right),(\mathrm{b}) * \mathrm{~K}^{+}: * \mathrm{Na}^{+}$, and (c) ${ }^{*} \mathrm{Ca}^{2+}: * \mathrm{Mg}^{2+}$ in SGU meltwaters and 1999 runoff. 

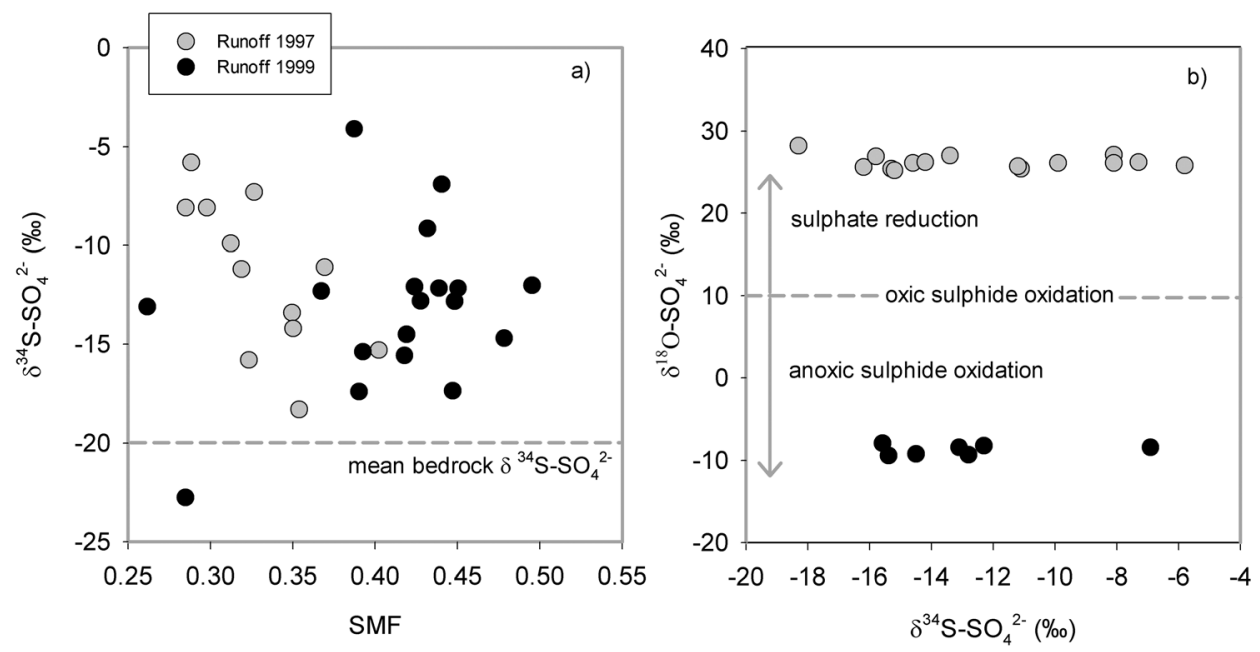

Figure 6. Associations between (a) $\mathrm{SMF}$ and the $\delta^{34} \mathrm{~S}_{-} \mathrm{SO}_{4}^{2-}$ and (b) between $\delta^{18} \mathrm{O}-\mathrm{SO}_{4}^{2-}$ and the $\delta^{34} \mathrm{~S}^{-\mathrm{SO}_{4}^{2-}}$ in bulk runoff from the $\mathrm{AD}(1997)$ and $\mathrm{CD}$ (1999) periods.

composition of sulphate in meltwaters between the two periods.

\section{Discussion}

\subsection{Interannual Changes in Hydrological Forcing Regime}

[20] Previous research based on 1994 and 1995 data has inferred that the SGU drains a snowmelt-fed subglacial distributed drainage system, involving meltwater flow via a basal debris layer [Wadham et al., 1998]. Decreases in $\mathrm{Cl}^{-}$ concentrations (Figure 2a) in the SGU between 1994 and 1997 provide clear evidence for strengthened coupling between the SGU and glacier surface icemelt production over this time period, attaining full coupling in 1997 when virtually all meltwater on the western margin was routed by the SGU. We note that rainfall during the study seasons was minimal (27-29 mm) compared with the amount of runoff produced by ice melt [Wadham et al., 1998; Cooper et al., 2002]. Hence, it is unlikely that rainfall was the driver of the hydrological evolution. We infer that relatively low, but steadily rising water fluxes (via increased icemelt) to the SGU between 1994 and 1997 (Figure 1) enabled the SGU to be maintained on the western margin over this time period. Gradual rising fluxes resulted in a concomitant enlargement of flow paths and decrease in SGU water pressures in the near terminal zone, resulting in drainage capture from the IMC. This sequence of events matches well to hydrological theory, which states that increased discharge is accompanied by decreasing water pressures in conduits, and that larger channels should capture drainage from smaller ones if hydrological connections exist [Röthlisberger, 1972]. Similar phenomena have been observed on the polythermal glacier, Erdmanbreen, Svalbard during the course of a single melt season, where rising discharges were accommodated increasingly by a subglacial upwelling, at the expense of drainage via ice-marginal channels [Hodson and Fergusson, 1999].

[21] If the progressive meltwater capture by the SGU from 1994 to 1997 is a result of falling water pressures in this environment compared to the IMC, the reversal of this pro- cess from 1997 to 1999 must reflect increasing pressures in the SGU relative to the IMC and the forcing of water into the latter drainage system. The high short-duration spring runoff event in 1999 (Figure 1) is held as a significant driver for this evolutionary behavior. This could have triggered drainage migration (e.g., by hydrofracture through cold ice), toward the more favorable (at this time) lower-pressure channelized system (IMC) [Röthlisberger, 1972], as is observed on temperate valley glaciers during discharge increases [Nienow et al., 1998]. Further increases in melt input during the 1999 melt season (maximum discharge = $46 \mathrm{~m}^{3} \mathrm{~s}^{-1}$ ) and strengthening of surface-to-bed hydrological connectivity, as indicated by lower $\mathrm{Cl}^{-}$concentrations, are inferred to have sustained this channelized routing of meltwater for the rest of the melt season. Whether the chemical weathering environment that supplied the SGU during the $\mathrm{AD}$ period contributed meltwaters to the IMC during the CD period can only be inferred from the crustal ion data, and will be conducted in subsequent discussion. We contend that the SGU was sustained as the dominant drainage feature on the western margin from 1994 to 1997 since the melt inputs in spring were small (Figure 1) and increased slowly, enabling the SGU to adjust its configuration to the rising water fluxes such that only moderate water pressures were attained. The frequent observation of pressurized subglacial upwellings on Svalbard glaciers, which shift their location as a response to frontal collapse in the glacier terminal region and changing melt rates is consistent with these assertions [Hodson and Fergusson, 1999; Hodson et al., 2000; Rippin et al., 2003; Wynn et al., 2006]. In particular, high spring melt rates and elevated pressures in subglacial upwellings were inferred by Rippin et al. [2003] to drive diversion of drainage from the upwellings to an ice-marginal/subglacial channel on another Svalbard glacier, Midtre Lovénbreen.

[22] The fact that $\mathrm{Cl}^{-}$concentrations decrease only slightly between 1997 (AD period) and 1999 (CD period) (Figures 2a and $2 \mathrm{~b}$ ) on Finsterwalderbreen, but ion associations are dramatically different (Figure 4) also supports the notion that changes observed in runoff biogeochemistry from the $\mathrm{AD}$ to the $\mathrm{CD}$ period were not simply a consequence of dilution but 
reflect fundamental changes in drainage system configuration (i.e., predominantly distributed drainage to predominantly channelized drainage). This sequence of events on Finsterwalderbreen provides a unique case study for identifying modes of coupling between subgacial drainage reorganization and biogeochemistry, as is discussed in section 5.2.

\subsection{Identification of Coupling Between Subglacial Hydrology and Bed Biogeochemistry During Drainage Reorganization}

[23] The reorganization of the drainage system on Finsterwalderbeen associated with the growth and disappearance of the SGU between 1994 and 1999 has a direct impact on biogeochemical processes in the Finsterwalderbreen catchment. Most strongly evident are the decreases in the concentrations of crustal ions in SGU meltwaters between 1994 and 1997, and particularly * $\mathrm{SO}_{4}^{2-}$ (Figures $3 \mathrm{~b}$ and 3d), signifying a reduction in residence times and rock:water ratios during SGU growth and meltwater capture from the IMC. The much smaller crustal ion decreases in bulk meltwaters from 1997 (AD period) to 1999 (CD period) (Figures 3 and 4) suggest similar residence times during these two time periods. However, dramatic shifts in ion associations (Figure 4) indicate different drainage flow path characteristics between the two periods, and hence chemical weathering processes. The details of this biogeochemical evolution are most clearly identified from associations between ions and from isotopic data as identified in the following discussion.

[24] Sulphate is commonly employed as a diagnostic indicator of distributed type drainage beneath glaciers, where reactive sulphide surfaces are continually produced in subglacial environments by comminution [Tranter et al., 1993]. The generally strong associations between $* \mathrm{SO}_{4}^{2-}$ and $\mathrm{HCO}_{3}^{-}$ (Figure $4 \mathrm{a}$ ) in the SGU during the AD period are consistent with strong coupling between carbonate dissolution and sulphide oxidation in this subglacial chemical weathering environment, where the following reaction applies:

$$
\begin{aligned}
& 4 \mathrm{FeS}_{2}+16 \mathrm{CaCO}_{3}+15 \mathrm{O}_{2}+14 \mathrm{H}_{2} \mathrm{O} \Longleftrightarrow 16 \mathrm{Ca}^{2+} \\
& +16 \mathrm{HCO}_{3}^{-}+8 \mathrm{SO}_{4}^{2-}+4 \mathrm{Fe}(\mathrm{OH})_{3}
\end{aligned}
$$

The relatively high concentrations of $* \mathrm{SO}_{4}^{2-}$ in the 1999 (CD period) meltwaters and lack of any strong relationship between ${ }^{*} \mathrm{SO}_{4}^{2-}$ and $\mathrm{HCO}_{3}^{-}$(Figure 4a) implies that, if $\mathrm{SO}_{4}^{2-}$ derives from sulphide oxidation, the protons generated by this process do not dissolve carbonates. However, the lack of any correlation between $\left(* \mathrm{Na}^{+}+* \mathrm{~K}^{+}\right)$and ${ }^{*} \mathrm{SO}_{4}^{2-}$ (Figure $4 \mathrm{~d}$ ) suggests that neither do protons from sulphide oxidation dissolve silicates. This leads us to infer that the provenance of $* \mathrm{SO}_{4}^{2-}$ in 1999 runoff is different to that of the SGU during the $\mathrm{AD}$ period. We contend that $\mathrm{SO}_{4}^{2-}$ in 1999 runoff derives from ice-marginal moraine pore waters, which are either entrained directly by ice-marginal channel waters and/or are added to the IMC via the numerous extraglacial streams that can be observed along the western glacier margin. Previous work shows that these pore waters are rich in $\mathrm{SO}_{4}^{2-}$, which is acquired initially by sulphide oxidation in moraines, but subsequently precipitates from solution as $\mathrm{Ca}^{2+}-\mathrm{Mg}^{2+}-\mathrm{SO}_{4}^{2-}$ salts due to freeze and evaporative concentration in summer [Cooper et al., 2002]. The salts redissolve during summer rain events, producing high $\mathrm{Ca}^{2+}-\mathrm{SO}_{4}^{2-}$ concentrations in moraine pore waters [Cooper et al., 2002]. These pore waters are typically saturated with respect to carbonate, and hence contain low concentrations of $\mathrm{HCO}_{3}^{-}$[Cooper et al., 2002]. The hypothesis that $\mathrm{SO}_{4}^{2-}$ in 1999 runoff is predominantly derived from the addition of $\mathrm{SO}_{4}^{2-}$ rich moraine pore waters is supported by the poor relationships between $\mathrm{HCO}_{3}^{-}$and both $* \mathrm{SO}_{4}^{2-}$ and ${ }^{*} \mathrm{Ca}^{2+}+* \mathrm{Mg}^{2+}$ in 1999 runoff, but a strong relationship between $* \mathrm{Ca}^{2+}+* \mathrm{Mg}^{2+}$ and $* \mathrm{SO}_{4}^{2-}$ (Figure 4). The much lower gradient $(1.1)$ in plots of $\left(* \mathrm{Ca}^{2+}+* \mathrm{Mg}^{2+}\right)$ versus $* \mathrm{SO}_{4}^{2-}$ (Figure $4 \mathrm{~b}$ ) compared with SGU meltwaters is consistent with the known composition of moraine pore waters, where $\mathrm{Ca}^{2+}$ and $\mathrm{SO}_{4}^{2-}$ occur in ratios of $\sim 1: 1$ [Cooper et al., 2002; Wadham et al., 2007]. The strong ice-marginal influence in the $C D$ period meltwaters matches with observations on coldbased glaciers, where contact of runoff with ice-marginal moraines contributes significant solute, and particularly $\mathrm{SO}_{4}^{2-}$, to bulk runoff [Tranter et al., 2002]. It suggests that during the $\mathrm{CD}$ period continuously draining, long-residence-time subglacial meltwaters on the western margin were either absent or very limited.

[25] Coincident with a shift in the dominant sulphate source between the $\mathrm{AD}$ and $\mathrm{CD}$ periods are changes in the redox chemistry of runoff, as displayed by the $\delta^{34} \mathrm{~S}$ and $\delta^{18} \mathrm{O}$ composition of sulphate in 1997 and 1999 bulk meltwaters (Figure 6). These isotopes are well known to provide information upon oxic versus anoxic sulphide oxidation, in addition to sulphate reduction in glaciers [Bottrell and Tranter, 2002; Wadham et al., 2004, 2007]. The degree of anoxia determines which of these three processes control the isotopic composition of the sulphate. Under oxic conditions, sulphides are oxidized by molecular oxygen (equation (2)), reverting to $\mathrm{Fe}(\mathrm{III})$ as conditions go suboxic to anoxic (equation (3)). As anoxia increases still further, and electron acceptors such as oxygen, nitrate and $\mathrm{Fe}(\mathrm{III})$ become depleted, sulphate reduction becomes viable, provided an organic carbon source exists (equation (4)). Oxidation of sulphate in an oxic environment should produce $\delta^{34} \mathrm{~S}^{-\mathrm{SO}_{4}^{2-}}$ values close to that of the bedrock sulphide (mean $=-17 \%$ ) [Wadham et al., 2007] and

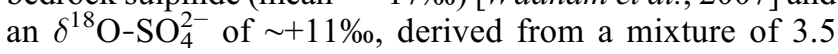
of 4 oxygen atoms from $\mathrm{O}_{2}(+23.7 \%)$ and 0.5 from water molecules $(-12$ to $-15 \%$ ), according to equation (2) [Dole et al., 1954; Kroopnick and Craig, 1972; Lloyd, 1967; Taylor et al., 1984; van Everdingen and Krouse, 1985; Holt and Kumar, 1991]:

$$
\begin{aligned}
& \mathrm{FeS}_{2}+3: 5 \mathrm{O}_{2}+\mathrm{H}_{2} \mathrm{O} \Longleftrightarrow 2 \mathrm{SO}_{4}^{2-}+2 \mathrm{Fe}^{2}++2 \mathrm{H}^{+} \\
& \mathrm{FeS}_{2}+\mathrm{Fe}^{3+}+8 \mathrm{H}_{2} \mathrm{O} \Longleftrightarrow 2 \mathrm{SO}_{4}^{2-}+2 \mathrm{Fe}^{2+}+16 \mathrm{H}^{2+} \\
& \mathrm{SO}_{4}^{2-}+2 \mathrm{CH}_{2} \mathrm{O} \Longleftrightarrow \mathrm{H}_{2} \mathrm{~S}+2 \mathrm{HCO}_{3}^{-}
\end{aligned}
$$

[26] Sulphate in neither the 1997 (AD period) nor the 1999 (CD period) bulk meltwaters displays an isotopic composition in line with that for oxic sulphide oxidation (Figure 6). The isotopic composition of sulphate during the AD period is consistent with the occurrence of bacterial sulphate reduction, where the consistency of $\delta^{18} \mathrm{O}$ at around $+25-27 \%$ is evidence that bacterial sulphate reduction has attained isotopic equilibrium [Wadham et al., 2004]. Here, 
the residual sulphate is enriched in $\delta^{34} \mathrm{~S}$ and $\delta^{18} \mathrm{O}$, since the lighter isotope is preferentially incorporated into the $\mathrm{H}_{2} \mathrm{~S}$ reaction product (equation (4)). Sulphate reduction in the SGU in 1997 provides one explanation for the low $* \mathrm{SO}_{4}^{2-}$ concentrations observed in this year, and their similarity to 1999 despite the higher concentrations of all other ions (Figure 4).

[27] There is no evidence for bacterial sulphate reduction in the $\mathrm{CD}$ period (1999) bulk runoff. Here, the $\delta^{18} \mathrm{O}_{-} \mathrm{SO}_{4}^{2-}$ is consistent with predominantly anoxic sulphide oxidation using $\mathrm{Fe}(\mathrm{III})$ (equation (3)), where the $\delta^{18} \mathrm{O}-\mathrm{SO}_{4}^{2-}$ adopts a value close to that of environmental water [Bottrell and Tranter, 2002], -12 to $-12.9 \%$ in this case.

[28] During the $\mathrm{CD}$ period, $\delta^{18} \mathrm{O}$ in $\mathrm{SO}_{4}^{2-}($ mean $=-8.9 \%$ in this case) is slightly higher than environmental water (Figure 6b), suggesting that a small proportion of sulphides are being oxidized under oxic conditions. Isotope mass balance can be used to calculate the mean percentage contribution of oxic versus anoxic sulphide oxidation to sulphate in the 1999 meltwaters in the following manner,

$$
\begin{aligned}
& \left(\delta^{18} \mathrm{O}_{-} \mathrm{SO}_{4}^{2-} \times \mathrm{SO}_{4}^{2-}\right)_{\text {bulk }}=\left(\delta^{18} \mathrm{O}^{-\mathrm{SO}_{4}^{2-}} \times \mathrm{SO}_{4}^{2-}\right)_{\text {oxic }} \\
& +\left(\delta^{18} \mathrm{O}_{-} \mathrm{SO}_{4}^{2-} \times \mathrm{SO}_{4}^{2-}\right)_{\text {anoxic-Fe(III) }}
\end{aligned}
$$

where $\mathrm{SO}_{4}^{2-}$ is sulphate concentration and $\delta^{18} \mathrm{O}-\mathrm{SO}_{4}^{2-}$ is the isotopic composition of the sulphate. Hence, $\left({ }^{18} \mathrm{O}^{-\mathrm{SO}_{4}^{2--}} \times \mathrm{SO}_{4}^{2-}\right)_{\text {bulk }}$ refers to the sample composition as measured. We set the $\left(\delta^{18} \mathrm{O}-\mathrm{SO}_{4}^{2-}\right)$ anoxic-Fe(III) to the mean $\delta^{18} \mathrm{O}-\mathrm{H}_{2} \mathrm{O}$ recorded in proglacial meltwaters $(-12.5 \%)$. We calculate the $\left(\delta^{18} \mathrm{O}-\mathrm{SO}_{4}^{2-}\right)_{\text {oxic }}$ as described above, taking $-12.5 \%$ as the mean $\delta^{18} \mathrm{O}-\mathrm{H}_{2} \mathrm{O}$ and assuming that 3.5 of 4 oxygen atoms in the sulphate produced derive from the atmosphere $\left(\delta^{18} \mathrm{O}=23.7 \%\right.$ ) and 0.5 from water (gives $+11.6 \%$ for $\delta^{18} \mathrm{O}-\mathrm{SO}_{4}^{2-}$ ). Equation (5) is then solved to give the mean concentrations of $\mathrm{SO}_{4}^{2-}$ produced oxically and anoxically, since $\left(\mathrm{SO}_{4}^{2-}\right)_{\text {bulk }}=\left(\mathrm{SO}_{4}^{2-}\right)_{\text {anoxic-Fe(III) }}$ $+\left(\mathrm{SO}_{4}^{2-}\right)_{\text {oxic. }}$ Calculations give values of $15 \%$ and $85 \%$, respectively, and are consistent with a predominantly anoxic source for most sulphate in these meltwaters.

[29] The $\delta^{18} \mathrm{O}-\mathrm{SO}_{4}^{2-}$ and $\delta^{34} \mathrm{~S}^{-\mathrm{SO}_{4}^{2-}}$ composition of $\mathrm{CD}$ period (1999) meltwaters plot within the range reported for proglacial moraine groundwaters [Wadham et al., 2007], with a scatter in $\delta^{34} \mathrm{~S}^{3} \mathrm{SO}_{4}^{2-}$ that arises from variation in the initial $\delta^{34} \mathrm{~S}$ bedrock composition [Wadham et al., 2007]. This is consistent with the hypothesis that most sulphate in 1999 runoff derives from the addition of moraine pore waters to the IMC. Typically $88 \%$ of sulphate is produced anoxically using $\mathrm{Fe}(\mathrm{III})$, and $12 \%$ is acquired under oxic conditions in moraine pore waters [Wadham et al., 2007], which is in broad agreement with the values calculated above.

[30] Isotope data are not available prior to 1997 and so it is impossible to infer anoxic versus oxic conditions in the SGU chemical weathering environment in 1994 and 1995. The data for 1997, however, strongly suggest that the SGU drained an anoxic environment where sulphate reduction was prevalent. We infer that the contribution to bulk runoff by long-residence-time subglacial drainage was small or absent following drainage reorganization between 1997 and 1999 (apart from during outburst events). Hence, during the CD period sulphate was acquired initially via anoxic sulphide oxidation in ice-marginal moraines, with temporary storage as sulphate salts that subsequently became mobilized by melt and input to the ice marginal channelized environment. This shift from microbially mediated sulphate reduction to sulphide oxidation under anoxic conditions implies a major change in the biogeochemical weathering environment draining the glacier western margin.

[31] Further information on microbial processes is encapsulated in the intercept values in plots of both $\mathrm{HCO}_{3}^{-}$ against $* \mathrm{SO}_{4}^{2-}$ and ${ }^{*} \mathrm{Ca}^{2+}+* \mathrm{Mg}^{2+}$ against $* \mathrm{SO}_{4}^{2-}$ (Figures $4 \mathrm{a}$ and $4 \mathrm{~b}$ and Table 2). Intercepts of $220 \mu \mathrm{eq} \mathrm{L}{ }^{-1}$ are commonly reported for subglacial and other meltwaters, and reflect the acquisition of $\mathrm{Ca}^{2+}+* \mathrm{Mg}^{2+}$ and $\mathrm{HCO}_{3}^{-}$, in the absence of $\mathrm{SO}_{4}^{2-}$, by carbonate hydrolysis (equation (6)) [Tranter et al., 2002]:

$$
\mathrm{CaCO}_{3}+\mathrm{H}_{2} \mathrm{O} \Longleftrightarrow \mathrm{Ca}^{2+}+\mathrm{HCO}_{3}^{-}+\mathrm{OH}^{-}
$$

[32] Increases above the $220 \mu \mathrm{eq} \mathrm{L}^{-1}$ intercept value in $\mathrm{AD}$ and $\mathrm{CD}$ period meltwaters point to an additional source of $\mathrm{HCO}_{3}^{-}$. In addition, the increases in the gradient of the association between $\mathrm{HCO}_{3}^{-}$and ${ }^{*} \mathrm{SO}_{4}^{2-}$ in 1995 meltwaters to above the maximum theoretical value for sulphide oxidation/ carbonate dissolution (gradient $=1$ ) suggest that some of this additional $\mathrm{HCO}_{3}^{-}$is linked to processes involving $\mathrm{SO}_{4}^{2-}$ (Table 2). The SGU is out of contact from the atmosphere, precluding an atmospheric source for excess $\mathrm{HCO}_{3}^{-}$between 1994 and 1997. The most plausible scenario in this case is that the $\mathrm{HCO}_{3}^{-}$is derived from $\mathrm{CO}_{2}$ produced via microbial respiration, which subsequently fuels chemical dissolution in a subglacial debris layer. Similar hypotheses have been used to explain excess $\mathrm{HCO}_{3}^{-}$in borehole waters from temperate valley glaciers [Tranter et al., 1996]. In 1995, the gradient of $>1$ for the association between $\mathrm{HCO}_{3}^{-}$and $\mathrm{SO}_{4}^{2-}$ (Table 2) may reflect bacterial sulphate reduction (and $\mathrm{HCO}_{3}^{-}$generation via the oxidation of organic carbon) in the very long residence time, low-discharge waters. A decrease in sulphate reduction as discharges rises in the $\mathrm{SGU}$ would reduce the excess $\mathrm{HCO}_{3}^{-}$ added to meltwaters by this process, steepening the overall gradient of the $\mathrm{HCO}_{3}^{-} / \mathrm{SO}_{4}^{2-}$ relationship. Essentially this is a drainage evolution trend.

[33] Since meltwaters follow a channelized/ice-marginal routing to the glacier terminus during the $\mathrm{CD}$ period (1999), an atmospheric source for the excess $\mathrm{HCO}_{3}^{-}$is plausible. One feature of the 1999 chemical data set, however, is inconsistent with this hypothesis. The strong relationships between $* \mathrm{Na}^{+}+* \mathrm{~K}^{+}$and $\mathrm{HCO}_{3}^{-}$in $\mathrm{AD}$ and $\mathrm{CD}$ period meltwaters (and weak associations between these cations and ${ }^{*} \mathrm{SO}_{4}^{2-}$ (Table 2)) suggest that some of the excess $\mathrm{HCO}_{3}^{-}$is balanced by $* \mathrm{Na}^{+}$and $* \mathrm{~K}^{+}$. The significant associations between dissolved $\mathrm{Si}$ and $\mathrm{HCO}_{3}^{-}$in 1995 and 1999 (Table 2), suggest that this is not simply an ion exchange phenomenon where $\mathrm{Ca}^{2+}$ and $\mathrm{Mg}^{2+}$ (acquired by $\mathrm{CO}_{2}$, and balanced by $\mathrm{HCO}_{3}^{-}$in solution) are exchanged for $\mathrm{K}^{+}$and $\mathrm{Na}^{+}$on sediment exchange sites. The inverse association between the ratio of $\left({ }^{*} \mathrm{Ca}^{2+}+* \mathrm{Mg}^{2+}\right):\left({ }^{*} \mathrm{Na}^{+}+* \mathrm{~K}^{+}\right)$and ionic strength (Figure 5a) is also consistent with this assertion. This relationship is opposite to what might be anticipated for ion exchange, where divalent ions are exchanged for monovalent ions as exchange surfaces become more selective at lower ionic strength [Tranter et al., 2002]. We note that this is contrary to 
the original interpretation for the high excess $* \mathrm{Na}^{+}$observed in SGU waters, when a smaller amount of data were available [Wadham et al., 1998]. If our current interpretation of the data is correct, some of the excess $\mathrm{CO}_{2}$ observed in meltwaters must directly dissolve silicates (up to $42 \%$ in 1995 as indicated by gradients of $* \mathrm{Na}^{+}+* \mathrm{~K}^{+}$versus $\mathrm{HCO}_{3}^{-}$(Table 2 )). $\mathrm{CO}_{2}$ derived from an atmospheric source is very unlikely to fuel the dissolution of silicate minerals. Unless the $\mathrm{CO}_{2}$ is generated close to silicate mineral weathering sites, the unfavorable kinetics of silicate dissolution [Tranter et al., 1993] will favor the carbonation of carbonates rather than silicates, according the following equations:

$$
\begin{aligned}
\mathrm{Ca}_{1-\mathrm{x}}\left(\mathrm{Mg}_{\mathrm{x}}\right) \mathrm{CO}_{3} & +\mathrm{CO}_{2}+\mathrm{H}_{2} \mathrm{O} \Longleftrightarrow(1-\mathrm{x}) \mathrm{Ca}^{2+} \\
& +\mathrm{xMg}^{2+}+2 \mathrm{HCO}_{3}^{-}(\mathrm{Mg}-)
\end{aligned}
$$

$\mathrm{CaAl}_{2} \mathrm{Si}_{2} \mathrm{O}_{8}+2 \mathrm{CO}_{2}+2 \mathrm{H}_{2} \mathrm{O} \Longleftrightarrow \mathrm{Ca}^{2+}+2 \mathrm{HCO}_{3}^{-}+\mathrm{H}_{2} \mathrm{Al}_{2} \mathrm{Si}_{2} \mathrm{O}_{8}$

where $\mathrm{Ca}_{1-\mathrm{x}}\left(\mathrm{Mg}_{\mathrm{x}}\right) \mathrm{CO}_{3}$ is magnesium calcite, $\mathrm{CaAl}_{2} \mathrm{Si}_{2} \mathrm{O}_{8}$ is anorthite (calcium feldspar), and $\mathrm{H}_{2} \mathrm{Al}_{2} \mathrm{Si}_{2} \mathrm{O}_{8}$ is weathered feldspar surfaces.

[34] This suggests that the $\mathrm{CO}_{2}$ was produced close to the sites of mineral dissolution, and most probably by microbial respiration. There are numerous reports in the literature where microorganisms accelerate the dissolution of a variety of silicates by the localized production of excess protons and organic ligands [Bennett et al., 2001; Liermann et al., 2000; Drever and Stillings, 1997; Brantley and Stillings, 1996]. In doing do, they derive macronutrients (e.g., $\mathrm{N}$ and $\mathrm{P}$ ) and trace nutrient metals such as Fe, V and Mn [Valsami-Jones et al., 1998; Brantley et al., 2001]. Recent laboratory studies have shown that subsurface microorganisms preferentially colonize nutrient-bearing silicate surfaces and subsequently dissolve the silicate matrix in order to extract and use limiting inorganic nutrients [Rogers et al., 1998]. The $\mathrm{Na}^{+}+\mathrm{K}^{+}$and $\mathrm{HCO}_{3}^{-}$data presented here provide evidence that similar processes may operate in a subglacial and ice-marginal environment, and in doing so accelerate chemical weathering rates. These assertions are consistent with microscopy studies which have detected high concentrations of microbial cells attached to clay grains in basal ice from the Greenland Ice Sheet, coincident with high concentrations of carbon dioxide and methane gas [Tung et al., 2006].

[35] The relative dominance of silicate versus carbonate dissolution in smaller valley glaciers, has been linked previously to meltwater residence times, such that silicate dissolution is enhanced in long-residence-time meltwaters as carbonates become exhausted or saturation is attained with respect to calcite [Sharp et al., 2002]. Given the inferred decrease in residence times and rock:water ratios for western margin meltwaters between the $\mathrm{AD}$ and $\mathrm{CD}$ periods, similar shifts in the balance between silicate and carbonate dissolution might be expected on our larger-scale system. Decreasing concentrations of $* \mathrm{Na}^{+}$and ${ }^{*} \mathrm{~K}^{+}$between 1994 and 1997 to the lowest measured concentrations in 1999 (Figures 4d and $4 \mathrm{e}$ ) suggest a reduction in the extent of silicate weathering as the upwelling captures an increasing volume of meltwater during the AD period and then evolves to a channelized drainage system during the $\mathrm{CD}$ period. Gradients of associations between $\mathrm{HCO}_{3}^{-}$and ${ }^{*} \mathrm{SO}_{4}^{2-}$ in SGU meltwaters from 1994 and 1997 fall below the theoretical value of 1 for coupled sulphide oxidation/carbonate dissolution, indicating coupling between sulphide oxidation and silicate dissolution (equation (9)),

$$
\begin{aligned}
& 4 \mathrm{FeS}_{2}+16 \mathrm{Na}_{1-\mathrm{x}} \mathrm{K}_{\mathrm{x}} \mathrm{AlSi}_{3} \mathrm{O}_{8}+15 \mathrm{O}_{2}+86 \mathrm{H}_{2} \mathrm{O} \\
& \quad \Longleftrightarrow 16(1-\mathrm{x}) \mathrm{Na}^{+}+16 \mathrm{xK}^{+}+8 \mathrm{SO}_{4}^{2-}+4 \mathrm{Al}_{4} \mathrm{Si}_{4} \mathrm{O}_{10} \\
& \quad+32 \mathrm{H}_{4} \mathrm{SiO}_{4}+\mathrm{Fe}(\mathrm{OH})_{3}
\end{aligned}
$$

where $\mathrm{Na}_{1-\mathrm{x}} \mathrm{K}_{\mathrm{x}} \mathrm{AlSi}_{3} \mathrm{O}_{8}$ is alkali feldspar and $\mathrm{Al}_{4} \mathrm{Si}_{4} \mathrm{O}_{10}$ is kaolinite.

[36] The high slope values in 1995 are an exception here and may reflect drainage evolution trends with increased microbial $\mathrm{CO}_{2}$ generation as discharges fall, as previously discussed. The lack of any significant relationship between $\mathrm{HCO}_{3}^{-}$and ${ }^{*} \mathrm{SO}_{4}^{2-}$ or between $* \mathrm{Na}^{+}+* \mathrm{~K}^{+}$and $* \mathrm{SO}_{4}^{2-}$ concentrations (Figures $4 \mathrm{a}$ and $4 \mathrm{~d}$ ) during the $\mathrm{CD}$ period suggests coupling between sulphide oxidation and silicate dissolution is very limited, if not absent. This is consistent with a decrease in residence times, as the SGU drainage system becomes more efficient and subsequently evolves to a channelized/ice-marginal system in 1999. Correspondingly the ratio of divalent (carbonate derived) to monovalent (silicate derived) ions relates inversely to ionic strength, and clearly indicates a shift from silicate dissolution (e.g., 1995) to increasing amounts of carbonate dissolution as the SGU develops during the $\mathrm{AD}$ period and subsequently evolves to channels between 1997 and 1999 (Figure 4a). This may also reflect the access of meltwaters to new sediment sources as drainage evolution takes place, and new sources of carbonate minerals are tapped by meltwaters and subsequently dissolved. Declining $* \mathrm{~K}^{+}: * \mathrm{Na}^{+}$ratios with decreasing ionic strength (Figure 5b) are difficult to link to silicate dissolution, but may reflect loss of $\mathrm{K}^{+}$during the formation of clay minerals in the SGU in 1995 and 1994 [Holland, 1978] when residence times were probably at their peak. Decreasing ${ }^{*} \mathrm{Ca}^{2+}: * \mathrm{Mg}^{2+}$ ratios with increased ionic strength (Figure 5c) are consistent with previous work which has suggested that dolomite dissolution is enhanced in long-residence-time systems [Sharp et al., 2002]. Hence, as SGU residence times and rock:water ratios decrease with increased icemelt input, carbonate (and limestone relative to dolomite) dissolution becomes increasingly important over silicate dissolution and clay mineral formation decreases. This situation was most strongly developed during the $\mathrm{CD}$ period, when meltwaters took a channelized and subsequently ice-marginal routing to the terminus.

\subsection{Evidence for and Quantification of Microbial Mediation of Chemical Weathering}

[37] Drainage reorganization between 1994 and 1999 is associated with clear changes in runoff biogeochemistry, with implications for microbial processes and microbial diversity in the Finsterwalderbreen catchment. Sulphate reduction in 1997 (AD period) is superseded by oxic and anoxic sulphide oxidation in 1999 (CD period), signifying a shift from anoxic to oxic/suboxic conditions. All three of these processes are mediated by different types of microorganisms [Wadham et al., 2004]. In addition, the change from anoxic to suboxic/ oxic conditions in the subglacial environment has implications for the composition of microbial (e.g., anaerobes versus 
Table 3. Calculations of Microbially Derived Solute Present During the SGU Meltwaters During the AD period (1994-1997) and Bulk Runoff During the CD Period (1999) at the Western Margin ${ }^{a}$

\begin{tabular}{|c|c|c|c|c|c|c|c|c|}
\hline & A & B & $\mathrm{C}$ & $\mathrm{D}$ & $\mathrm{E}$ & $\mathrm{F}$ & G & $\mathrm{H}$ \\
\hline Parameter & $\begin{array}{c}\text { Excess } \\
\mathrm{Ca}^{2+}+\mathrm{Mg}^{2+}\end{array}$ & $\begin{array}{l}\text { Maximum } \\
\text { Sulphate } \\
\text { by Sulphide } \\
\text { Oxidation }\end{array}$ & $\begin{array}{l}\text { Minimum } \\
\text { Sulphate } \\
\text { by Sulphide } \\
\text { Oxidation }\end{array}$ & $\begin{array}{c}\text { Maximum } \\
\text { Microbial } \\
\text { Solute } \\
\text { Concentration }\end{array}$ & $\begin{array}{c}\text { Minimum } \\
\text { Microbial } \\
\text { Solute } \\
\text { Concentration }\end{array}$ & $\begin{array}{c}\text { Mean Ion } \\
\text { Concentration }\end{array}$ & $\%$ MAXSolute ${ }_{\text {mic }}$ & $\%$ MINSolute $_{\text {mic }}$ \\
\hline SGU 1994 & 468 & 475 & 89.0 & 1890 & 1110 & 2900 & 65.0 & 38.0 \\
\hline SGU 1995 & 58.0 & 604 & 218 & 1320 & 552 & 3940 & 33.0 & 14.0 \\
\hline SGU 1997 & 120 & 267 & 0.00 & 774 & 240 & 1890 & 41.0 & 13.0 \\
\hline 1999 Runoff & 139 & 263 & 0.00 & 804 & 278 & 1740 & 46.0 & 16.0 \\
\hline Mean SGU & & & & 1330 & 635 & & 47.0 & 23.0 \\
\hline Mean CDS & & & & 804 & & & 46.0 & \\
\hline
\end{tabular}

${ }^{\mathrm{a}}$ Units are in microequivalents per liter $\left(\mu \mathrm{eq} \mathrm{L}^{-1}\right)$.

aerobes) that dominate at the glacier bed. During both the AD and $\mathrm{CD}$ periods, the role of microbes is apparent in dissolving silicate minerals through the generation of $\mathrm{CO}_{2}$ close to mineral weathering sites. This probably took place within a subglacial debris layer during the AD period and within icemarginal moraines during the $\mathrm{CD}$ period. Concentrations of $\mathrm{Na}^{+}$and $\mathrm{K}^{+}$generated by this process decrease as the SGU becomes more efficient and subsequently evolves to a channelized drainage system. This suggests that sectors of the SGU hydrological environment became progressively less favorable for microbial habitation during drainage reorganization.

[38] The role of microbes in mediating chemical weathering is clear during both the AD and CD data sets, providing a unique opportunity to quantify for the first time the glacial solute flux attributable to microbial activity. In doing so, we define two specific microbial influences on runoff chemistry: (1) the anoxic microbial oxidation of sulphide minerals and (2) the generation of $\mathrm{CO}_{2}$ via microbial respiration. Both these processes generate protons which can be consumed in chemical dissolution processes. We quantify the average proportion of solute in meltwaters from 1994 to 1999 which is "microbially generated" by these two processes to give maximum and minimum estimates of microbial solute acquisition (see Table 3, where letter labels in the following text refer to parameter identifiers in the table).

[39] The first process concerns solute acquired due to microbial $\mathrm{CO}_{2}$ generation. We assume that the $\mathrm{CO}_{2}$ generated by microbial respiration (A) is calculated from the intercepts in plots of $\mathrm{HCO}_{3}^{-}$versus $* \mathrm{SO}_{4}^{2-}$ (Table 2 ) minus the theoretical value for carbonate hydrolysis $\left(220 \mu \mathrm{eq} \mathrm{L}^{-1}\right)$ [Tranter et al., 2002]. This assumes that all excess $\mathrm{CO}_{2}$ is derived from microbial respiration, rather than the atmosphere; an assumption that is dealt with in section 5.2. We note that the standard error on the $1994 \mathrm{SO}_{4}^{2-} / \mathrm{HCO}_{3}^{-}$association is high $\left(110 \mu \mathrm{eq} \mathrm{L}^{-1}\right)$ due to the small number of samples. We assume that the excess $\mathrm{HCO}_{3}^{-}$concentration is balanced by an equivalent amount of cation charge, which has to be the case for stoichiometric reasons. Hence the excess $\mathrm{HCO}_{3}^{-}$is multiplied by two to give the total solute attributable to microbial $\mathrm{CO}_{2}$ production. This method gives a minimum estimate of the excess "microbial" $\mathrm{CO}_{2}$, since it excludes $\mathrm{Na}^{+}$ and $\mathrm{K}^{+}$which may be acquired by carbonation using microbial $\mathrm{CO}_{2}$. The same calculation is performed for our maximum and minimum estimates.

[40] The second process concerns solute acquired due to microbial mediation of sulphide oxidation. Since we do not know the degree to which microbes are involved in oxic sulphide oxidation within the catchment, we assume for simplicity that only anoxic sulphide oxidation is microbially mediated, which is well established [Taylor et al., 1984]. We know from the isotopic composition of sulphate in the 1999 runoff that $85 \%$ of all sulphide was oxidized anaerobically in moraines in this year. Hence, we calculate that the microbially generated $\mathrm{SO}_{4}^{2-}$ in this case is equal to $85 \%$ of the mean $\mathrm{SO}_{4}^{2-}$ concentration. We would expect this estimate to rise to $100 \%$ in a more isolated subglacial system such as the SGU, where sulphate reduction is already occurring. Since there is no direct evidence that $100 \%$ of the sulphate is produced anoxically in the SGU, we calculate a minimum and maximum estimate of the amount of sulphate produced microbially. In the maximum estimate (B), we assume that $100 \%$ of the sulphate in the SGU is produced anoxically, mediated by microbes. This assumes that the amount of oxygen delivered to the subglacial environment by regelation $(5-6 \mathrm{~mm}$ melt per year) is also minimal, which is consistent with previous findings [Wadham et al., 2008]. In the minimum case, we assume that $386 \mu \mathrm{eq} \mathrm{L}^{-1}$ of sulphate can be produced by oxic sulphide oxidation using oxygen supplied in oxygen saturated snowmelt [Tranter et al., 2002], with any excess above this quantity added by anoxic sulphide oxidation. Hence, we subtract this "oxic value" from the total mean sulphate concentration in each water type to give a minimum estimate (C) of the mount of sulphate that must be produced anoxically. For both the SGU and 1999 data, we take the concentration of microbially derived sulphate and assume that each molar equivalent of sulphate is balanced by an equivalent quantity of cation charge. Hence values for microbially derived sulphate are multiplied by two to give minimum and maximum estimates of the solute produced microbially by this process.

[41] Maximum (D) and minimum (E) estimates of solute attributable to microbial processes are calculated according to equations (10) and (11), and finally expressed as a percentage of the mean ion concentration (F) $\left(\%\right.$ MAXSolute ${ }_{\text {mic }}$

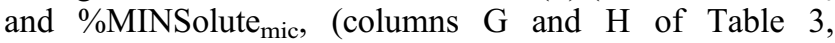
respectively)) (for the 1999 data, only one estimate exists and is labeled as \%MAXSolute ${ }_{\text {mic }}$ in this case):

$$
\begin{aligned}
& \% \text { MAXSolute }_{\text {mic }}(\mathrm{G})=100 *\left[\frac{2(\mathrm{~A}-220)+(\mathrm{B})}{\mathrm{G}}\right] \\
& \text { \%MINSolute }_{\text {mic }}(\mathrm{H})=100 *\left[\frac{2(\mathrm{~A}-220)+(\mathrm{C})}{\mathrm{G}}\right]
\end{aligned}
$$


These calculations show that the amount of solute that is microbially generated in subglacial and ice-marginal environments could be as high as $50-65 \%$ of the total solute flux. This supports previous work that has demonstrated a correlation between the metabolic pathways employed by the major phylogenetic groups of microorganisms and runoff chemistry, suggesting that microbes are directly involved in mineral weathering [Skidmore et al., 2005]. It also suggests that microbial processes may play some role in enhancing chemical weathering rates beneath glaciers, which have been shown to exceed the continental average for the same specific discharge [Reynolds and Johnson, 1972; Anderson et al., 1997; Wadham et al., 1997; Hodson et al., 2000].

[42] The impact of SGU hydrological evolution on microbially generated solute is evident in the gradual decrease in the calculated microbially generated solute concentrations between 1994 and 1997, and the decrease in the maximum percentage contribution to total solute from $1994(65 \%)$ to 1995/1997 (39-46\%). This suggests that the increased efficiency of the SGU associated with rising icemelt inputs impacted on microbial activity. This may have taken place either by loss of microbial habitats in the subglacial debris layer, or by increasing isolation of these habitats relative to the dominant flow paths as the drainage system became more efficient and concentrated into a smaller number of pathways. Contrary to what one might expect, the mean percentage of solute attributable to microbial activity was similar between the AD period (1997: 47\%) and the CD (1999: 46\%), suggesting that although the shift in drainage between the two periods lowered overall concentrations of microbially derived solute (Table 3, column D), the proportion of solute that can be said to be microbially derived did not change substantially (Table 3, column G). This suggests that debris rich glacial environments (ice-marginal or subglacial) both constitute favorable environments for microbial activity, as has been hypothesized elsewhere [Tranter et al., 2005].

\subsection{Implications for Biogeochemical Processes Beneath Ice Sheets}

[43] The $\mathrm{AD}$ and $\mathrm{CD}$ data sets presented here provide a unique opportunity to infer biogeochemical processes beneath continental-scale ice sheets in two specific ways. First, the growth and evolution of the SGU between 1994 and 1997 enable inferences to be made regarding the balance of biogeochemical processes that prevail in subglacial environments as residence times and rock:water ratios increase, with 1994 and 1995 representing the longest-residence-time waters and 1997 the shortest. This provides a predictive framework for the biogeochemistry of large continental-scale ice sheets, where residence times are likely to be prolonged (days to months on Greenland and years beneath Antarctica), rock:water ratios are high and there is very limited contact with atmospheric gases (e.g., deformable sediments beneath ice streams). Second, the AD to $\mathrm{CD}$ transition at Finsterwalderbreen can be used to predict changes in bed biogeochemistry that might occur on contemporary ice sheets as the zone of surface melt expands with increased air temperatures [Steffen et al., 2004] and new areas of the bed begin to receive inputs from surface melt. We examine these two scenarios in turn in the following discussion by testing a series of hypotheses with regard to chemical dissolution under ice sheets.
[44] 1. Hypothesis 1 states: The significance of microbes in mediating subglacial chemical weathering is greater in longer-residence-time drainage systems, as might be found beneath ice sheets. We previously identified two processes that are attributable to microbial activity in chemical data sets from Finsterwalderbreen. First is the generation of microbial $\mathrm{CO}_{2}$ that subsequently fuels the dissolution of carbonate and silicate minerals. Second is the anoxic oxidation of sulphide minerals using $\mathrm{Fe}(\mathrm{III})$, which is a microbially mediated process. In section 5.3 , we calculated the potential solute fluxes from Finsterwalderbreen that are linked to these two types of microbial activity. If Hypothesis 1 is correct, we would expect to find a decrease in solute loads attributable to microbial activity, both in absolute terms and as a proportion of total solute loads, during the $\mathrm{AD}$ period as water residence times decrease. We might also expect to see progressively weakening relationships between $\mathrm{HCO}_{3}^{-}$ and $\left(* \mathrm{Na}^{+}+* \mathrm{~K}\right)$ during the $\mathrm{AD}$ period, inferred to reflect decreased coupling between the microbial generation of $\mathrm{CO}_{2}$ and silicate dissolution. It is clear from data during the $\mathrm{AD}$ period at Finsterwalderbreen that changes in residence times and rock:water ratios from 1994 to 1997 impacted on the biogeochemistry of meltwaters issuing from the SGU in these years. Beyond the decrease in ion concentrations observed due to rising icemelt input to the SGU chemical weathering environment, a shift in the balance of biogeochemical processes is identified. First, the role of microbes in mediating chemical dissolution decreased, both in absolute terms and as a proportional contribution to total solute loads during the $\mathrm{AD}$ period (Table 3, columns E and $\mathrm{G}$ and $\mathrm{H}$ ), with the strongest microbial influence observed in 1994. Second, the role of microbial $\mathrm{CO}_{2}$ in dissolving silicates decreased from 1994/ 1995 to 1997 (Figures 4 and 5) as residence times decreased. These observations support Hypothesis 1, indicating that microbes have the greatest impact on subglacial chemical weathering when meltwater residence times are prolonged, by the generation of protons via microbial respiration and microbially mediated sulphide oxidation. We would expect these processes to be further developed still on ice sheets, where flow paths may be $>1000 \mathrm{~km}$ long and water residence times are, therefore, prolonged.

[45] 2. Hypothesis 2 states: Silicate dissolution becomes dominant over carbonate dissolution as meltwaters become saturated with respect to calcite in long-residence-time drainage systems. This is likely to be enhanced beneath ice sheets. Since silicate dissolution generates predominantly $\mathrm{Na}^{+}$and $\mathrm{K}^{+}$ions and carbonate dissolution generates $\mathrm{Mg}^{2+}$ and $\mathrm{Ca}^{2+}$ ions, the ratio of the monovalent to divalent cations largely indicates the relative dominance of silicate versus carbonate dissolution between the different study periods. Under Hypotheses 2, we would expect to see low ratios of $\left({ }^{*} \mathrm{Ca}^{2+}+* \mathrm{Mg}^{2+}\right):\left({ }^{+} \mathrm{Na}^{+} * \mathrm{~K}^{+}\right)$in longer-residence-time waters (e.g., AD period) compared with low-residence-time waters (CD period). We would also expect to see an increase in this ratio as meltwater residence times in the SGU decreased between 1995 and 1997. Our data set shows that silicate (including biotite) and dolomite dissolution were enhanced relative to carbonate and limestone dissolution, respectively, in the longer-residence-time SGU meltwaters (1994 and 1995), as evidenced by low ratios of $\left({ }^{*} \mathrm{Ca}^{2+}+\right.$ $\left.{ }^{*} \mathrm{Mg}^{2+}\right):\left({ }^{*+} \mathrm{Na}^{+}{ }^{*} \mathrm{~K}^{+}\right)$(Figure 5a). Correspondingly, an increase in the importance of carbonate dissolution was 
observed as residence times and rock:water ratios decreased from 1995 to 1999 , as evident from the inverse association between $\left(* \mathrm{Ca}^{2+}+* \mathrm{Mg}^{2+}\right):\left({ }^{+} \mathrm{Na}^{+} * \mathrm{~K}^{+}\right)$and ionic strength (Figure 5a). These observations support Hypothesis 2. One might expect the features of the longer-residencetime chemical data sets (1994 and 1995) to be even more developed beneath continental-scale ice sheets. Within a deformable sediment layer beneath an ice stream one might expect to find high rates of microbial activity (including $\mathrm{CO}_{2}$ generation via respiration and $\mathrm{SO}_{4}^{2-}$ produced by microbially mediated sulphide oxidation), which in turn fuels silicate and carbonate dissolution via released protons, and drives the bed anoxic as the oxidation of sulphides and organic carbon consumes available oxygen.

[46] 3. Hypothesis 3 states: Anoxia increases as water residence times increase within sub-ice sheet environments that are remote from the atmosphere, resulting in the dominance of anaerobic microbial processes, such as sulphate reduction. Anoxic conditions may be inferred from the $\delta^{18} \mathrm{O}-\mathrm{SO}_{4}^{2-}$ and $\delta^{34} \mathrm{~S}_{-} \mathrm{SO}_{4}^{2-}$ of runoff, as discussed in section 5.2. If the concept that anoxia increases with increased residence times holds, the $\delta^{18} \mathrm{O}-\mathrm{SO}_{4}^{2-}$ and $\delta^{34} \mathrm{~S}_{-} \mathrm{SO}_{4}^{2-}$ of runoff from Finsterwalderbreen should show evidence for decreasing anoxia as water residence times decrease during the $\mathrm{AD}$ period and between the $\mathrm{AD}$ and $\mathrm{CD}$ periods. Isotope data presented in this paper provide strong evidence that meltwater residence times have a strong impact on the degree of anoxia attained in the subglacial environment. During the AD period, when high solute concentrations imply prolonged water:rock contact times, sulphate reduction was apparent where the residual sulphate was enriched in $\delta^{34} \mathrm{~S}$ and $\delta^{18} \mathrm{O}$. Sulphate reduction no longer occurred during the CD period and sulphate was produced by a combination of anoxic and oxic sulphide oxidation. This is consistent with Hypothesis 3. The degree of anoxia would be expected to be high beneath ice sheets, where flow paths may be $>1000 \mathrm{~km}$ long. Here, one might expect all sulphide oxidation to proceed anoxically using $\mathrm{Fe}(\mathrm{III})$ and sulphate reduction to occur, provided an organic carbon substrate exists. For ice sheets where there is an organic carbon supply (e.g., overridden soils, vegetation and/or marine/lake sediments) one might predict methanogenesis to occur, as has been suggested elsewhere [Weitemeyer and Buffett, 2006; Wadham et al., 2008].

[47] The above hypotheses regarding subglacial biogeochemistry assume long-residence-time/high rock:water ratios for subglacial meltwaters beneath ice sheets. These constraints are satisfied in distributed-type drainage systems where melt inputs are low, for example, a deformable sediment layer beneath an ice stream and the interior wet-based parts of Greenland and Antarctica. They also hold relevance for the chemical composition of water likely to be evacuated from the Antarctic ice sheet to the ocean during subglacial lake drainage events [Fricker et al., 2007; Wingham et al., 2006]. A very different biogeochemical environment might be expected to prevail if the melt inputs to these long-residencetime subglacial environments increased. For example, an increase in the aerial extent of surface melt generation on the Greenland Ice Sheet might lead to the initiation of melt input to the bed in previously untapped areas [Steffen et al., 2004]. Under these conditions, one might expect distributed drainage environments to evolve to channels in a similar manner to the 1999 CD period, with inputs of water and solute from moraine in situations where there is contact between runoff and ice-marginal sediments. Using data from Finsterwalderbreen, we test a series of hypotheses regarding potential changes in subice sheet biogeochemistry during evolution from distributed drainage forms to channels.

[48] 1. Hypothesis 1 states: The subglacial environment sees an overall decrease in anoxia, and shift toward oxic/ suboxic conditions in channel marginal zones. Within the context of this hypothesis, one might expect to see isotopic evidence for a shift in sulphate reduction/anoxic sulphide oxidation to only anoxic or oxic sulphide oxidation as meltwater residence times decrease. Certainly data from Finsterwalderbreen support this idea, as sulphate reduction during the AD period is replaced by anoxic/oxic sulphide oxidation during the CD period. We would anticipate these changes to prevail in subglacial channels and channelmarginal zones beneath ice sheets, which act as oxic, high Eh-corridors at the bed. Processes such as sulphate reduction and methanogenesis, however, may persist in anoxic microenvironments or poorly hydrologically connected zones. These evolutionary trends may produce a shift in microbial community composition from anaerobes to aerobes in some basal environments.

[49] 2. Hypothesis 2 states: Increased drainage efficiency and reduced rock:water ratios in channelized zones will result in a decrease in the importance of microbial activity in enhancing solute fluxes from an ice sheet. Under this hypothesis, both lower total microbial solute fluxes and a lower microbial contribution to total solute fluxes would be expected if drainage efficiency and rock:water contact times decrease at a glacier or ice sheet bed. A reduction in total microbial activity is not seen during the $\mathrm{AD}$ to $\mathrm{CD}$ drainage transition at Finsterwalderbreen due to the contact of runoff in 1999 with ice-marginal moraine pore waters, where there is significant biological activity [Wadham et al., 2007]. In the absence of this interaction, a subice sheet system of channels and continually flushed channel-marginal sediments would be likely to display lower microbial activity due to lower rock:water ratios and contact times and high meltwater flushing rates.

[50] 3. Hypothesis 3 states: The input of surface meltwater to new areas of the ice sheet bed and the subsequent evolution of a distributed drainage system to channels will be accompanied by evolution from a silicate-dominated to carbonate-dominated chemical weathering regime. Under this hypothesis, one might expect to see an increase in the ratio of $\mathrm{Ca}^{2+}+* \mathrm{Mg}^{2+}: * \mathrm{Na}^{+}+* \mathrm{~K}^{+}$as meltwater residence times decrease, indicating a greater proportional contribution of carbonate versus silicate dissolution to solute loads. The transition between the $\mathrm{AD}$ and $\mathrm{CD}$ periods on Finsterwalderbreen is accompanied by a progressive decrease in the significance of silicate and dolomite (versus calcite) dissolution, as indicated by increasing ratios of $\mathrm{Ca}^{2+}+* \mathrm{Mg}^{2+}$ : $* \mathrm{Na}^{+}+* \mathrm{~K}^{+}$and ${ }^{*} \mathrm{Ca}^{2+}: * \mathrm{Mg}^{2+}$. We would expect similar trends to occur upon initiation of channelized flow at the bed of an ice sheet, driven by a reduction in meltwater residence times. This would produce a decrease in saturation indices with respect to calcite, and carbonate dissolution would be favored above the kinetically less favorable silicate dissolution. The same argument follows for the dissolution of dolomite, where present. This may have implications for resident microbes, which depend upon silicate dissolution to 
release trace quantities of essential life elements such as $\mathrm{N}$ and P [Valsami-Jones et al., 1998; Brantley et al., 2001].

\section{Conclusions}

[51] The above synthesis provides a unique insight to the relationship between subglacial hydrology and biogeochemical processes beneath large, long-residence-time glacier systems. During its growth period (1994-1997), the SGU at Finsterwalderbreen constitutes an anoxic subglacial weathering environment where favorable conditions for sulphate reduction are apparent, silicate dissolution is enhanced and microbes are important in driving chemical dissolution (including that of silicates). The subsequent evolution of this environment to a channelized/ice-marginal system in which residence times and rock:water ratios are reduced witnesses a shift in runoff biogeochemistry. During this CD period, most solute derives from chemical weathering in ice-marginal moraines, and particularly the dissolution of $\mathrm{Ca}^{2+}-\mathrm{Mg}^{2+}-\mathrm{SO}_{4}^{2-}$ salts, with a reduced importance of silicate versus carbonate dissolution. Both the AD and CD period data sets provide first time compelling evidence for coupling between $\mathrm{CO}_{2}$ generated by microbial respiration and the dissolution of silicate mineral surfaces; suggesting that biofilms may be important in accelerating chemical dissolution in subglacial and icemarginal sedimentary environments. In both cases, microbial activity (via sulphide oxidation and $\mathrm{CO}_{2}$ generation) accounts for up to $\sim 50 \%$ of the solute flux from the SGU and icemarginal moraine environment. This is consistent with work which has suggested that there are strong linkages between microbial activity and chemical dissolution processes beneath glaciers. The reorganization of drainage between 1994 and 1999 provides insight into the likely balance of biogeochemical processes under ice sheets. This has relevance given the current scientific interest in Antarctic subglacial lakes [Priscu et al., 2005; Siegert et al., 2007], and the potential shift in subglacial drainage that may occur beneath the Greenland Ice Sheet with an increased extent of surface melting and input to previously untapped basal environments [Steffen et al., 2004]. The interior regions of ice sheets are likely to be characterized by even longer residence times and a greater degree of isolation from the atmosphere than the SGU. In this type of chemical weathering environment one might expect; enhanced silicate dissolution, high anoxia and the prevalence of sulphate reduction and methanogenesis, diverse microbial communities which map onto specific $\mathrm{Ph} / \mathrm{Eh}$ microniches at the bed and a chemical weathering regime that is essentially driven by microbial $\mathrm{CO}_{2}$ and microbially mediated sulphide oxidation using $\mathrm{Fe}$ (III). Under conditions of distributed system drainage evolution to channels triggered by enhanced melt inputs such as might be observed on the Greenland Ice Sheet in the coming decades, one might expect the opposite set of biogeochemical processes, namely, oxic/suboxic conditions (with an absence of sulphate reduction/methanogenesis), a reduced significance of silicate versus carbonate dissolution, reduced microbial involvement in chemical dissolution and a decrease in microbial diversity due to substrate limitations. These inferences provide a predictive framework for subice sheet biogeochemistry, which may become important in the coming decade as deep, subice sheet environments in Greenland and Antarctica are sampled for the first time.
[52] Acknowledgments. This work was supported by NERC grants GR9/2550 and GST/02/2204, NERC studentships GT24/98/ARCI/8 and GT4/94/116/A, the European Union Environment Programme grant EN5V-CT93-0299, and the Phillip Leverhulme Prize to Jemma Wadham.

\section{References}

Anderson, S. P. (2007), Biogeochemistry of glacial landscape systems, Annu. Rev. Earth Planet. Sci., 35, 375-399, doi:10.1146/annurev. earth.35.031306.140033.

Anderson, S. P., J. I. Drever, and N. F. Humphrey (1997), Chemical weathering in glacial environments, Geology, 25, 399-402, doi:10.1130/00917613(1997)025<0399:CWIGE > 2.3.CO;2

Bennett, P. C., J. R. Rogers, W. J. Choi, and F. K. Hiebert (2001), Silicates, silicate weathering and microbial ecology, Geomicrobiol. J., 18, 3-9, doi:10.1080/01490450151079734.

Bottrell, S. H., and M. Tranter (2002), Sulphide oxidation under partially anoxic conditions at the bed of the Haut Glacier d'Arolla, Switzerland, Hydrol. Processes, 16, 2363-2368, doi:10.1002/hyp.1012.

Brantley, S. L., and L. L. Stillings (1996), Feldspar dissolution at 25 degrees C and low pH, Am. J. Sci., 296, 101-127, doi:10.2475/ajs.296.2.101.

Brantley, S. L., L. Liermann, M. Bau, and S. Wu (2001), Uptake of trace metals and rare earth elements from hornblende by a soil bacterium, Geomicrobiol. J., 18, 37-61, doi:10.1080/01490450151079770.

Cooper, R. J., J. L. Wadham, M. Tranter, R. Hodgkins, and N. Peters (2002), Groundwater hydrochemistry in the active layer of the proglacial zone, Finsterwalderbreen, Svalbard, J. Hydrol. Amsterdam, 269, 208223, doi:10.1016/S0022-1694(02)00279-2.

Dallmann, W. K., A. Hjelle, Y. Ohta, O. Salvigsen, M. G. Bjornerud, E. C. Hauser, H. D. Maher, and C. Craddock (1990), Van Keulenfjorden, with explanatory text, in Geological Map of Svalbard, Temakart 15, sheet B11G, scale 1:100,000, Norsk Polarinstitutt, Oslo.

Das, S., I. Joughin, M. D. Behn, I. M. Howat, M. A. King, D. Lizarralde, and M. Bhatia (2008), Fracture propagation to the base of the Greenland Ice Sheet during supraglacial lake drainage, Science, 320, 778-781, doi:10.1126/science.1153360.

Dole, M., G. A. Lange, D. P. Rudd, and D. A. Zaukelies (1954), Isotopic composition of atmospheric oxygen and nitrogen, Geochim. Cosmochim. Acta, 6, 65-78, doi:10.1016/0016-7037(54)90016-2.

Drever, J. I., and L. L. Stillings (1997), The role of organic acids in mineral weathering, Colloids Surf. A, 120, 167-181, doi:10.1016/S0927-7757 (96)03720-X.

Foght, J. M., J. Aislabie, S. Turner, C. E. Brown, J. Ryburn, D. J. Saul, and W. Lawson (2004), Culturable bacteria in subglacial sediments and ice from two Southern Hemisphere glaciers, Microb. Ecol., 47, 329-340, doi:10.1007/s00248-003-1036-5.

Fricker, H. A., T. Scambos, R. Bindshadler, and L. Padman (2007), An active subglacial water system in West Antarctica mapped from space, Science, 315, 1544-1548, doi:10.1126/science.1136897.

Gaidos, E., B. Lanoil, T. Thorsteinsson, A. Graham, M. Skidmore, S.-K. Han, T. Rust, and B. Popp (2004), A viable microbial community in a subglacial volcanic crater lake, Iceland, Astrobiology, 4, 327-344, doi:10.1089/ast.2004.4.327.

Hodson, A., A. M. Anesio, M. Tranter, A. Fountain, M. Osborn, J. Priscu, J. Laybourne-Parry, and B. Sattler (2008), Glacial ecosystems, Ecol. Monogr., 78, 41-67, doi:10.1890/07-0187.1.

Hodson, A. J., and R. Fergusson (1999), Fluvial suspended sediment transport from cold and warm-based glaciers in Svalbard, Earth Surf. Processes Landforms, 24, 957-974, doi:10.1002/(SICI)1096-9837(199910) 24:11<957::AID-ESP19>3.0.CO;2-J.

Hodson, A., M. Tranter, and G. Vatne (2000), Contemporary rates of chemical denudation and atmospheric $\mathrm{CO}_{2}$ sequestration in glacier basins: An Arctic perspective, Earth Surf. Processes Landforms, 25, 1447-1471, doi:10.1002/1096-9837(200012)25:13<1447::AID-ESP156>3.0.CO;2-9.

Holland, H. D. (1978), The Chemistry of Atmosphere and Oceans, WileyInterscience, New York.

Holt, B. D., and R. Kumar (1991), Oxygen isotope fractionation for understanding the sulphur cycle, in SCOPE 43: Stable Isotopes in the Assessment of Natural and Anthropogenic Sulphur in the Environment, edited by H. R. Krouse and V. A. Grinenko, pp. 27-41, Wiley, Chichester, U. K. Kroopnick, P., and H. Craig (1972), Atmospheric oxygen isotopic composition and solubility fractionation, Science, 175, 54-55, doi:10.1126/science. 175.4017 .54

Liermann, L. J., A. S. Barnes, B. E. Kalinowski, X. Zhou, and S. L. Brantley (2000), Microenvironments of $\mathrm{pH}$ in biofilms grown on dissolving silicate surfaces, Chem. Geol., 171, 1-16, doi:10.1016/S0009-2541(00)00202-3.

Lloyd, R. M. (1967), Oxygen-18 composition of oceanic sulphate, Science, 156, 1228-1231, doi:10.1126/science.156.3779.1228. 
Mikucki, J. A., C. M. Foreman, B. Sattler, W. Berry-Lyons, and J. Priscu (2004), Geomicrobiology of Blood Falls: An iron rich saline discharge at the terminus of the Taylor Glacier, Antarctica, Aquat. Geochem., 10, 199-220, doi:10.1007/s10498-004-2259-x.

Nienow, P. W., M. Sharp, and I. C. Willis (1998), Seasonal changes in the morphology of the subglacial drainage system, Haut Glacier d'Arolla Earth Surf. Processes Landforms, 23, 825-843, doi:10.1002/(SICI) 1096-9837(199809)23:9<825::AID-ESP893>3.0.CO;2-2.

Priscu, J. C., M. C. Kennicutt II, R. E. Bell, S. A. Bulat, J. C. Ellis-Evans, V. V. Lukin, J.-R. Petit, R. D. Powell, M. J. Siegert, and I. Tabacco (2005), Exploring subglacial Antarctic lake environments, Eos Trans. $A G U, 86(20), 193$, doi:10.1029/2005EO200001.

Raiswell, R., M. Tranter, L. G. Benning, M. Siegert, R. De'ath, P. Huybrechts, and T. Payne (2006), Contributions from glacially derived sediment to the global iron (oxyhydr)oxide cycle: Implications for iron delivery to the oceans, Geochim. Cosmochim. Acta, 70, 2765-2780, doi:10.1016/j. gca.2005.12.027.

Raiswell, R., L. G. Benning, L. Davidson, and M. Tranter (2008), Nanoparticulate iron minerals in icebergs and glaciers, Mineral. Mag., 72(1), 345-348, doi:10.1180/minmag.2008.072.1.345.

Reynolds, R. C. J., and N. M. Johnson (1972), Chemical weathering in the temperate glacial environment of the northern Cascade Mountains, Geochim. Cosmochim. Acta, 36, 537-554, doi:10.1016/0016-7037(72) 90074-9.

Rippin, D., I. Willis, N. Arnold, A. Hodson, J. Moore, J. Kohler, and H. Björnsson (2003), Changes in geometry and subglacial drainage of Midtre Lovenbreen, Svalbard, determined from digital elevation models, Earth Surf. Processes Landforms, 28, 273-298, doi:10.1002/esp.485.

Rogers, J. R., P. C. Bennett, and W. J. Choi (1998), Feldspars as a source of nutrients for microorganisms, Am. Mineral., 83, 1532-1540.

Röthlisberger, H. (1972), Water pressure in intra- and subglacial channels, J. Glaciol., 11, 177-203.

Sharp, M., J. Parkes, B. Cragg, I. J. Fairchild, H. Lamb, and M. Tranter (1999), Widespread bacterial populations at glacier beds and their relationship to rock weathering and carbon cycling, Geology, 27, 107-110, doi:10.1130/0091-7613(1999)027<0107:WBPAGB>2.3.CO;2.

Sharp, M., R. Creaser, and M. Skidmore (2002), Strontium isotope composition of runoff from a glaciated carbonate terrain, Geochim. Cosmochim. Acta, 66, 595-614, doi:10.1016/S0016-7037(01)00798-0.

Siegert, M. J., et al. (2007), Exploration of Ellsworth Subglacial Lake: A concept paper on the development, organisation and execution of an experiment to explore, measure and sample the environment of a West Antarctic subglacial lake, Rev. Environ. Sci. Biotechnol., 6, 161-179, doi:10.1007/s11157-006-9109-9.

Skidmore, M., J. M. Foght, and M. Sharp (2000), Microbial life beneath a high Arctic glacier, Appl. Environ. Microbiol., 66, 3214-3220, doi:10.1128/AEM.66.8.3214-3220.2000.

Skidmore, M., S. P. Anderson, M. Sharp, J. Foght, and B. D. Lanoil (2005), Comparison of microbial community compositions of two subglacial environments reveals a possible role for microbes in chemical weathering processes, Appl. Environ. Microbiol., 71, 6986-6997, doi:10.1128/ AEM.71.11.6986-6997.2005.

Steffen, K., S. V. Nghiem, R. Huff, and G. Neumann (2004), The melt anomaly of 2002 on the Greenland Ice Sheet from active and passive microwave satellite observations, Geophys. Res. Lett., 31, L20402, doi:10.1029/2004GL020444.

Taylor, B. E., M. C. Wheeler, and D. K. Nordstrom (1984), Isotope composition of sulphate in acid mine drainage as a measure of bacterial oxidation, Nature, 308, 538-541, doi:10.1038/308538a0.

Tranter, M., G. H. Brown, R. Raiswell, M. J. Sharp, and A. M. Gurnell (1993), A conceptual model of solute acquisition by Alpine glacial meltwaters, J. Glaciol., 39, 573-581.

Tranter, M., G. H. Brown, A. J. Hodson, and A. Gurnell (1996), Hydrochemistry as an indicator of subglacial drainage system structure of alpine and sub-polar environments, Hydrol. Processes, 10, 541-556, doi:10.1002/(SICI)1099-1085(199604)10:4<541::AID-HYP391>3.0. $\mathrm{CO} ; 2-9$.
Tranter, M., M. J. Sharp, H. R. Lamb, G. H. Brown, B. P. Hubbard, and I. C. Willis (2002), Geochemical weathering at the bed of the Haut Glacier d'Arolla-A new model, Hydrol. Processes, 16, 959-993, doi:10.1002/hyp.309.

Tranter, M., M. Skidmore, and J. L. Wadham (2005), Hydrological controls on microbial communities in subglacial environments, Hydrol. Processes, 19, 995-998, doi:10.1002/hyp.5854.

Tung, H. C., P. B. Price, N. E. Brammall, and G. Vrdolijak (2006), Microorganisms metabolizing on clay grains in 3-km-deep Greenland basal ice, Astrobiology, 6, 69-86, doi:10.1089/ast.2006.6.69.

Valsami-Jones, E., J. McLean, S. McEldowney, H. Hinrichs, and A. Pili (1998), An experimental study of bacterially induced dissolution of K-feldspar, Mineral. Mag., 62A(3), 1563-1564.

van Everdingen, R. O., and H. R. Krouse (1985), The isotope composition of sulphate generated by bacterial and abiological oxidation, Nature, 315 , 395-396, doi:10.1038/315395a0.

Wadham, J. L., A. J. Hodson, M. Tranter, and J. A. Dowdeswell (1997), The rate of chemical weathering beneath a quiescent, surge-type, polythermal-based glacier, southern Spitsbergen, Ann. Glaciol., 24, 27-31.

Wadham, J. L., A. J. Hodson, M. Tranter, and J. A. Dowdeswell (1998), The hydrochemistry of meltwaters during the ablation season at a high Arctic, polythermal-based glacier, south Svalbard: I. The ablation season, Hydrol. Processes, 12, 1825-1849, doi:10.1002/(SICI)1099-1085 (19981015)12:12<1825::AID-HYP669>3.0.CO;2-R.

Wadham, J. L., M. Tranter, and J. A. Dowdeswell (2000), Hydrochemistry of meltwaters draining a polythermal-based, high Arctic glacier, south Svalbard: II. Winter and early spring, Hydrol. Processes, 14, 17671786, doi:10.1002/1099-1085(200007)14:10<1767::AID-HYP103>3.0. CO;2-Q.

Wadham, J. L., R. Hodgkins, R. J. Cooper, and M. Tranter (2001), Evidence for seasonal subglacial outburst events at a polythermal glacier, Finsterwalderbreen, Svalbard, Hydrol. Processes, 15, 2259-2280, doi:10.1002/hyp.178

Wadham, J. L., S. Bottrell, M. Tranter, and R. Raiswell (2004), Stable isotope evidence for microbial sulphate reduction at the bed of a polythermal high Arctic glacier, Earth Planet. Sci. Lett., 219, 341-355, doi:10.1016/S0012-821X(03)00683-6.

Wadham, J. L., R. J. Cooper, M. Tranter, and S. Bottrell (2007), Evidence for widespread anoxia in the proglacial zone of an Arctic glacier, Chem. Geol., 243, 1-15, doi:10.1016/j.chemgeo.2007.04.010.

Wadham, J. L., M. Tranter, M. J. Sharp, and S. Tulaczyk (2008), Subglacial methanogenesis: A potential climatic amplifier?, Global Biogeochem. Cycles, 22, GB2021, doi:10.1029/2007GB002951.

Weitemeyer, K., and B. A. Buffett (2006), Accumulation and release of methane from clathrates from below the Laurentide and Cordilleran ice sheets, Global Planet. Change, 53, 176-187, doi:10.1016/j.gloplacha. 2006.03.014.

Wingham, D. J., M. J. Siegert, A. Shepherd, and A. S. Muir (2006), Rapid discharge connects subglacial lakes, Science, 440, 1033-1036.

Wynn, P., A. Hodson, and T. Heaton (2006), Chemical and isotopic switching within the subglacial environment of a high Arctic glacier, Biogeochemistry, 78, 173-193, doi:10.1007/s10533-005-3832-0.

S. Bottrell and R. Raiswell, School of Earth and Environment, Faculty of Environment, Environment Building, University of Leeds, Leeds, LS2 9JT, UK.

R. Cooper, The Macaulay Land Use Research Institute, Aberdeen, AB15 8QH, UK.

R. Hodgkins, Department of Geography, Loughborough University, Epinal Way, Loughborough, LE11 3TU, UK.

A. J. Hodson, Department of Geography, University of Sheffield, Winter Street, Sheffield, S10 2TN, UK.

M. Tranter and J. L. Wadham, School of Geographical Sciences, University of Bristol, University Road, Bristol, BS8 1SS, UK. (j.1. wadham@bristol.ac.uk) 